\title{
Differential market valuations of board busyness across alternative banking models
}

\author{
Marwa Elnahass $^{1}\left(\mathbb{D} \cdot\right.$ Kamil Omoteso $^{2} \cdot$ Aly Salama $^{1} \cdot$ Vu Quang Trinh $^{3}$
}

Published online: 3 September 2019

(c) The Author(s) 2019

\begin{abstract}
This study comparatively assesses the influence of board busyness (i.e., multiple directorships of outside directors) on stock market valuations of both Islamic and conventional banks. For a sample of listed banks from 11 countries for the period 2010-2015, results show that board busyness is differentially priced by investors depending on the bank type. In conventional banks, board busyness is significantly and positively valued by the stock market. This result suggests that investors perceive some reputational benefits arising from a busy board (e.g., extended industry knowledge, established external networks or facilitation of external market sources). In contrast, we find no supporting evidence on the market valuations of board busyness in Islamic banks. This result might be attributed to, both, the complex governance structure and the uniqueness of the business model which require additional effective monitoring, relative to that employed in conventional banking. Our results also show that investors provide significantly low market valuations for busy Shari'ah advisory board which acts as an additional layer of governance in Islamic banks. Findings in this study offer important policy implications to international banking studies and regulations governing countries with dual-banking systems.
\end{abstract}

Keywords Firm valuations $\cdot$ Board busyness $\cdot$ Banking systems $\cdot$ Stock market

JEL Classification C23 · G01 · G21 · G28 · L50 · M41

\section{Introduction}

Regulators and market participants in capital markets have long emphasised on the critical role of the board of directors, as a core corporate governance mechanism, in promoting a country's economic growth and financial stability. A weak system of governance tends to offer substantial managerial opportunities to engage in risk-taking activities and fraudulent acts. Extant literature (e.g., Mallette and Fowler 1992; Faleye et al. 2018; Lu and Boateng 2017; Jouida 2019) documents that an effective board of directors can monitor top

Marwa Elnahass

marwa.elnahas@newcastle.ac.uk

1 Newcastle University Business School, Newcastle University, Newcastle upon Tyne, UK

2 University of Derby, Derby, UK

3 Huddersfield Business School, University of Huddersfield, Huddersfield, UK 
management on behalf of shareholders to reduce information asymmetry between managers and shareholders and thereby lessen agency costs. Resource dependence theorists assert that a board of directors is "a provider of resources, such as legitimacy, advice and council links to other organizations" (Hillman and Dalziel 2003, p. 383). Therefore, the quality of board monitoring and their engagements in managerial decision-making can have direct implications on firm value (Yermack 1996; Lin and Liu 2009; Liu 2015; Meng et al. 2018). Moreover, the uniqueness of governance in banking alongside the opacity related to several banking transactions imply a dominant impact of effective monitoring by the board of directors on investors' trust and optimism (Adams and Mehran 2003; Faleye and Krishnan 2017). Appointing an outside busy board member (i.e., holding multiple directorships) can, hence, affect investors' perceptions of their firm value. Furthermore, in line with the agency theory, investors are likely to pay more for bank equity when their interests are aligned with those of directors and managers. In other words, a bank market value is likely to increase as the agency conflicts diminish because such lower agency costs can effectively protect investors' wealth. From this perspective, board busyness can influence bank market value by either restricting or encouraging managers from expropriating bank resources. This depends on the levels of agency costs and the complexity of a bank business model.

Arguably, busy boards can offer reputational benefits to their firms such as extended business networking/connections and quick access to market resources (Brennan et al. 2016). Holding multiple board seats can also promote effective monitoring due to rich experience and valuable skills from serving many firms (Jiraporn et al. 2008). This might enhance the quality of long-term decision making, and hence, such reputational benefits might lead to favourable implications on firm value (Field et al. 2013; Muravyev et al. 2016; Chou and Feng 2018). In contrast, other prior studies still suggest that board busyness can result in over-commitment and limited availability by boards who might be unable to fulfil their fiduciary duties and scrutinise risk-taking activities (Fich and Shivdasani 2006; Falato et al. 2014; Chou and Feng 2018), leading to adverse impact(s) on firm valuation.

Evidence on the market valuations of busy boards of directors is limited (e.g., Ferris et al. 2003; Cashman et al. 2012), focused on non-financial firms (i.e., the industrial sector) and provided mixed findings. Within the banking setting, examining stock market valuations (see Caprio et al. 2007; Belkhir 2009; Zulkafli et al. 2010) is restricted to focus only on other corporate governance mechanism and characteristics (e.g., ownership structure, shareholder protection laws, board size, and CEO duality). Therefore, relatively little is known about whether board busyness can either improve or detriment the bank market value. Moreover, none of the prior studies in banking has given attention to the possible systematic differences of stock market valuations for busy boards across alternative bank types.

An ideal setting for such an investigation is the unique systems of governance and business models employed by the Islamic versus conventional banks. ${ }^{1}$ Investigating the effects of busy boards across the two systems is important to the on-going debate associated with

\footnotetext{
1 The operations of Islamic banks are principally driven by a constrained banking model, which inherits both moral accountability values and legal responsibilities (Abdelsalam et al. 2016). Islamic banks operate on a business model that prohibits interests, complex derivatives, short-selling, aggressive risk-taking and speculation while they encourage risk-profit sharing between the firms and their depositors. Meanwhile, conventional banks provide their services on interest-basis.
} 
factors contributing to the resilience and stability of both banking sectors (see Čihák and Hesse 2010; Abedifar et al. 2013; Beck et al. 2013). The rapid growth of Islamic banks implies that the impact of this bank type on the global economy might be substantial. ${ }^{2}$ The financial crisis in 2007 has also extended the attraction of exploring the market valuation of the Islamic banking model in comparison to conventional banking by practitioners and monetary authorities, to explore a viable and resilient alternative financial system to the conventional banking system (Wilson 2009). Islamic banks conduct operations based primarily on profit-loss sharing (PLS) arrangements, in which contracts between the banks and their depositors are equity-based (Olson and Zoubi 2008; Mollah et al. 2017).

The governance structure employed by Islamic banks is likely to be more complicated than that of conventional (Safieddine 2009; Mollah and Zaman 2015). In both bank types, the board of directors is responsible for the implementation of strategic decisions, protection of the shareholders' interest and maximisation of the bank value. However, for Islamic banks, under the constrained banking model and the nature of the products/services offered, board of directors has additional responsibilities related to the establishment of the appropriate Shari'ah governance framework besides the development of relevant policies to ensure that all activities are conducted in compliance with the Shari'ah law (Quttainah et al. 2013). Furthermore, for Islamic banks, additional agency costs are likely to be associated with the Islamic banking model. This is due to a peculiar institutional environment in Islamic banks including the special bank-depositors' relationship. ${ }^{3}$ Moreover, unlike the single governance-layer in conventional banks (i.e., board of directors), Islamic banks are subject to a double-governance mechanism by a Shari'ah Supervisory Board (i.e., SSB) in addition to their regular board of directors. ${ }^{4}$ Decisions by the board of directors depend much on the supervision effectiveness of SSB for Shari' ah compliance (Mollah and Zaman 2015). SSB is hence referred as "supra authority" which monitors the board of directors' decisions to ensure that they execute the ex-ante approved products/services (Beekun and Badawi 2005; Godlewski et al. 2016; Alsaadi et al. 2017). Finally, the structure and features of Islamic banking governance indicate that the popularity and the scarcity of experts in Shari' ah legitimacy on a global basis for both boards of directors and SSB have contributed to the busyness of the two boards in Islamic banks. ${ }^{5}$

Accordingly, the natures, qualities, and commitments of the board of directors in the two bank types are dissimilar (Mollah et al. 2017) and can have implications on investors' valuation of board busyness. Under the presence of structural differences between conventional and Islamic banking business models, our premise is that differential stock market valuations of board busyness across the two bank types is plausible. Investors within the

\footnotetext{
2 The annual growth of Islamic banking is around 20\% in 2012 (Malkawi 2013). Until 2015, their total assets reach $\$ 1.38$ trillion, which is projected to further increase to $\$ 6.5$ trillion by 2020 (IFSB 2017). From 1998 to 2005, Islamic banks showed tremendous growth in their assets by $111 \%$ while conventional banks only grew by $6 \%$ (Khan 2010).

3 With the absence of representation on the board of directors for depositors, Islamic bank managers have full control of the investment process of depositors' funds which suggest high agency problems.

4 AAOIFI standard defines Shari' ah supervisory boards as "specialised jurists, particularly in Islamic law and finance, entrusted with the duty of directing, reviewing and supervising the activities related to Islamic finance to ensure they comply with Shari'ah rules and principles" (Lahsasna 2010; p. 217). The SSB has both consultative and supervisory functions to support the board of directors.

5 Few Shari'ah scholars who are highly experienced in the inter-disciplines of Shari'ah law and finance (Alnasser and Muhammed 2012) do exist worldwide. Therefore, there is a limited number of the most prominent scholars dominate the Islamic banking industry nowadays (Mollah and Zaman 2015).
} 
two banking sectors may hold different perceptions of the oversight and resource-creation roles of outside boards depending on the banking business model employed and the structure of governance including the need for additional monitoring like Shari'ah governance. A lower firm valuation of board busyness in Islamic banks is predicted when compared to their conventional counterparts. This is justified by the extended agency conflicts and the unique business model of Islamic banking, which requires effective scrutiny from two different boards (i.e., the board of directors and the SSB).

We empirically examine whether board busyness is differently valued by investors engaging with the Islamic versus conventional banking sectors. We use an international sample of 386 bank-year observations for listed Islamic and conventional banks operating in 11 countries between 2010 and 2015. For the full sample (i.e., Islamic and conventional banks), results show that busy board of directors is significantly associated with the high bank value. Conditional on the bank type, we find strong evidence of differential market valuations of busy boards between Islamic and conventional banks. For conventional banks, investors tend to perceive board busyness as significantly increasing bank value. In contrast, investors in Islamic banks seem not to perceive board busyness, which reports insignificant results. We take a step ahead to study the channels underlying the board busyness and bank value among the two bank types. Our empirical analyses involve studying agency conflicts and board compensation channels. We find that board busyness is likely to exacerbate agency conflicts within Islamic banks leading to lower market valuation. However, this is less pronounced in conventional banks. Furthermore, a busy board of directors is associated with low compensation pay-outs. This is more evidential in conventional than Islamic banks. It is also more expensive to appoint a busy SSB than non-busy SSB.

In additional analyses, board busyness becomes significantly perceived as reducing the Islamic bank value as the degree of board directorships increases. Moreover, Islamic banks with busy SSB exhibit significantly low market value. We also find an inverted U-shaped non-linear relationship between busy SSB and stock market valuation: at lower degrees of board busyness, investors tend to highly price busy SSB, yet at higher degrees of board busyness, the market value of Islamic banks decreases. Our results are robust in several model specifications (i.e., propensity score matching, first-differenced regressions and GMM) as well as alternative measures for board busyness and bank performance.

To our knowledge, this study is the first to offer comparative assessments between Islamic and conventional banking market valuations by utilising an important board attribute such as busyness. The study's findings are timely to the current debate of the complexity of corporate governance of Islamic versus conventional banking (e.g., Mollah and Zaman 2015; Mollah et al. 2017; Lassoued et al. 2017; Alandejani et al. 2017; Alqahtani et al. 2017; Elnahass et al. 2018). We extend prior literature studies through highlighting to the influence of institutional characteristics and governance structures on having distinct firm valuations for busy boards within the two banking sectors. This study also contributes to the stream of banking valuation studies in conventional banking (e.g., Caprio et al. 2007; Elyasiani and Zhang 2015) and identifies the possible preferential impacts of having a busy board. Moreover, results highlighting the adverse effects of SSB busyness on an Islamic bank value also add to a sizeable body of literature on corporate governance in Islamic banking discussing the importance of this board (e.g., Quttainah et al. 2013; Abdelsalam et al. 2016).

The findings in this study provide valuable policy implications to regulators and market participants involved in the two banking sectors. For conventional banks, board busyness offers reputational benefits to banks which tend to contribute to shareholder wealth maximisation. However, such reputational benefits of busy boards tend not to hold in complex 
agency environments and constrained business models like Islamic banking. Furthermore, findings suggest that effective Shari'ah monitoring seems to be an essential determinant for enhancing the market valuations of this banking sector. Our results suggest that market participants engaging with the Islamic banking sector tend to be more sensitive to the SSB busyness than the board of directors' busyness. Having busy SSB seems to be negatively perceived by investors probably due to concerns related to the effectiveness of Shari'ah governance and moral accountability of the bank. Overall findings in this study raise a call to regulators and policymakers for the need to develop stricter criteria and guidelines to govern outside board directorships. The study also provides valuable insights to inform the debates raised by several external organisations regarding restrictions on the board multiple-directorship (e.g., National Association of Corporate Directors 1996 and the Council of Institutional Investors-CII 2003).

The rest of this paper is structured as follows: the next section presents the background and theoretical framework. Section 3 discusses hypothesis development. Section 4 and 5 present data and sample, and methodology, respectively. Section 6 reports empirical results while Sect. 7 provides additional testing. Section 8 presents the sensitivities and robustness checks. Finally, Sect. 9 concludes.

\section{Background and theoretical framework}

A board of directors (BOD) is responsible for approving a bank's policies, procedures, and business strategies as well as resolving investor/manager agency conflicts by setting compensation, appointing, replacing and overseeing managers who cannot create value for investors. Strong governance implies an active role by boards in monitoring top managers, mitigating risks and enhancing long-term resilience all of which should be, in principle, positively priced by investors. This argument is in line with the Slack Resource theory which suggests that firms with higher market valuation tend to have more economic resources to invest in the long-term improvements of their governance mechanisms and board monitoring quality. This investment will lead to future higher firm valuation, creating a virtuous circle (Pae and Choi 2011). However, entrenched managers may have incentives to divert slack resources or free cash flows for their private interests (e.g., building an empire, increasing their compensation) (Jensen 1986). In such a case, those managers are less likely to use slack resources to invest in strengthening different governance mechanisms. Therefore, monitoring the effectiveness of outside directors for those managers becomes indispensable. Any reputational damage to the BODs, thus, could constitute a severe threat to the survival of the firm, and hence, have an adverse impact on the market valuations.

From an agency theory perspective, ineffective boards can exacerbate agency conflicts between investors and managers by encouraging managerial perquisites and private control benefits (Jensen and Meckling 1976; Chen 2016; Boateng et al. 2017; Harkin et al. 2019). As being financially independent of insiders, a board should have the ability to withstand pressure from their bank to manipulate earnings and monitor the operating process. Hence, appointing outside directors should in principle strengthen corporate governance to alleviate the shareholder/manager and controlling-shareholders/minority-shareholders agency conflicts (Choi et al. 2007; Machuga and Teitel 2009). 
Previous studies on firm valuation and value relevance ${ }^{6}$ (e.g., Ball et al. 2003; Zoubi et al. 2016; Goncalves et al. 2017) document that the value relevance of accounting information is important not only for investors but also for standard setters as it provides useful insights into several accounting issues. Moreover, information on non-financial indicators such as corporate governance mechanisms can still influence the ability of investors to price their firms and forecast future stock performance (Bose 2014; Yeh et al. 2015).

The empirical research on the relationship between governance and firm value suggests that well-governed firms are associated with a higher stock market valuation (e.g., Yermack 1996; Gompers et al. 2003; Sami et al. 2011; de Haan and Vlahu 2013; Nguyen et al. 2015). Other sets of studies show that investors are likely to reward firms with effective governance by assigning a high firm value (see Epstein et al. 1994; Brown and Caylor 2006; Dittmar and Mahrt-Smith 2007; Choi and Jung 2008; Baek et al. 2009). Pae and Choi (2011) also state that investors often require a lower cost of equity for well-governed firms as these factors can mitigate agency costs and enhance disclosure transparency within firms. Caprio et al. (2007) study the effects of governance (i.e., ownership structure, shareholder protection laws, cash flow rights, and empowering official supervisory and regulatory agencies) on the market valuations of banks. Similarly, Belkhir (2009) and Zulkafli et al. (2010) provide evidence on the relationship between bank value and governance (i.e., board characteristics, board size and CEO duality).

With the growing opaqueness surrounding the banking industry, research studies investigating the association between firm valuation and board busyness are still scarce. Only within the non-financial sector, studies have provided mixed evidence on the relationship between board busyness and firm value. For example, Fich and Shivdasani (2006) show for a sample of large US industrial firms (i.e., Forbes 500) that busy outside directors might not be effective monitors on any board, and hence, negatively affect market-to-book ratios and governance. Cashman et al. (2012) also find that the presence of busy directors has a negative impact on market value, but only of large firms (i.e., S\&P 500). Contrary, Perry and Peyer (2005) find that outside directorships for executives are likely to enhance firm value, possibly through either external networking opportunities or through signalling of high quality for the managerial decision-making process. They argue that outside directorships only negatively affect market valuations when the firm has high agency problems. Furthermore, Ferris et al. (2003) find no evidence that multiple directorships can shirk their responsibilities to serve on board committees and suggest an insignificant linkage between multiple directorships and the likelihood of securities fraud litigation.

Investigating the board busyness attribute emerges from two opposing perspectives. The first one is the busyness view which contends that busy outside directors may fail in fulfilling their monitoring role as they are sitting on many boards and are likely to have relatively less time available to collect/process information that would support business strategies (Hart 1995; Jackling and Johl 2009). Busy outside directors tend to be less effective to monitor and control managerial opportunism, unlikely to provide thoughtful advice to executives, and, therefore, board busyness is expected to be detrimental to firms in the long-term (Falato et al. 2014; Zhang 2016). Therefore, board busyness is associated with weak governance structures (Core et al. 1999). As weak governance structure is perceived by market participants leading to low market valuations, market participants are more

\footnotetext{
6 Value relevance is defined as the ability of an accounting measure to capture and summarise information that affects the firm value. This measure is significantly associated with a set of information used by investors in a firm's valuation such as share prices, stock returns, or market capitalisation (Barth et al. 2001).
} 
likely to penalise their firms for poor monitoring (Core et al. 1999; Fich and Shivdasani 2006).

The second view is the reputational benefits emerging from appointing a busy board. Board busyness is associated with high popularity and reputational capital in the external labour market (Masulis and Mobbs 2014). Holding multiple board seats can also improve a board member experience, objectiveness, and proficiency in evaluating and overseeing the managers' decisions (Harris and Shimizu 2004; Brennan et al. 2016). Arguably, their social ties make them excellent advisors and value-enhancing directors (Field et al. 2013). Busy directors thus can be assessed as valuable assets for their firms given their extensive and updated industry-specific knowledge. This board can, hence, offer a vital supportive role to inside directors (Clifford et al. 2017) as well as have established outside networks that could facilitate access to market sources and other strategic benefits. These reputational benefits can be positively priced by investors, and board busyness can be perceived as value-enhancing for a firm (Muravyev et al. 2016).

Moreover, in line with the signalling theory, holding information content constant, firm valuations may depend on how information is categorised and presented (Peng and Xiong 2006). The extent of disclosure, reporting transparency, and news outcomes signal good news on favourable aspects related to financial and corporate information which in turn might lead to stock price over-valuing. Under a transactional setting, when an investor is considering purchasing stock from a listed firm, this firm might be interested in signalling the hidden value of the equity investment (Allen and Faulhaber 1989) or reporting extensive corporate information relating to strong governance mechanisms including effective BODs (Higgins and Gulati 2006). Conveying information on strong corporate governance to stakeholders eliminates the information asymmetry between firm managers and investors (e.g., Ballas et al. 2012; Bergh et al. 2014; Mitra et al. 2019).

\section{Hypothesis development}

With the lack of evidence related to the possible effect of board busyness on stock market valuations of banks in general terms, additional research gaps emerge which particularly pertain to studying this effect within different bank types (i.e., Islamic and conventional banks). Based on the two distinct contradicting views of the busy board discussed above (i.e., the busyness versus reputational effects) and the limited evidence within the banking setting, we conjecture that board busyness can have either positive or negative implications on stock market valuations. However, the direction of the association will be ultimately conditional on the system of corporate governance employed, the levels of the agency costs and the banking business model, all of which could vary depending on the bank type.

\subsection{Market valuations of busy board of directors in Islamic and conventional banks}

Islamic banks are distinguished from conventional banks by several aspects of their business models. Unlike conventional banks, depositors/investors in Islamic banks have no right to intervene in the financial and operating management of their funds (Abdel Karim 2001). Therefore, managers in Islamic banks have full control of the investment process of depositors' funds which offer several opportunities to pursue their own benefits at the expense of their investors, which can result in investors carrying additional agency costs (Abdelsalam et al. 2016). Moreover, additional agency costs arise in Islamic banking given 
those outside directors who are expert in Shari'ah legitimacy are scarce worldwide, and there are few numbers of prominent and expert outside directors who dominate the Islamic banking industry.

In Islamic banking, board busyness can reduce the monitoring ability of outside directors to effectively mitigate and prevent wealth expropriation from minority shareholders which could lead to substantial agency costs. Such expectation can be attributed to the limited time and attention given by busy outside directors to scrutinise the bank's operations against risky and opportunistic activities/transactions, which is strictly impermissible according to the Shari' ah governance. Furthermore, operating on a constrained banking model might lead investors' uncertainty regarding the streams of future cash flows which must be invested in compliance with the Shari'ah rules. Poor monitoring by busy boards can further destroy the trust of investors with regards to managers' discretion and expropriation of rents (e.g., Caprio et al. 2007). Therefore, investors may anticipate that additional cash flow might be diverted, and a smaller portion of the firm's profits will be paid off as dividends (La Porta et al. 2002).

In contrast, conventional banks operate on a relatively less complex business model which facilitate alternative investment channels, quick access to market sources and risk diversifications through trading in financial instruments which are prohibited by Islamic banks (e.g., derivatives and options). Therefore, the various reputational benefits associated with board busyness are more likely to be available and pervasive for conventional banking to enhance the bank equity value, when compared to Islamic banking. Signalling such reputational effects to the stock market is expected to affect investors' perceptions of board busyness positively. Moreover, in line with the representativeness heuristic theory, individuals are likely to overestimate "the probability of an event based on the similarity between its properties and the parent population's properties"; for example, comparing the firm position with its competitors using several benchmark indicators (Chan et al. 2004, p.5). For a conventional bank that appoints outside directors who serve in many banks, investors may overestimate the probability that these directors are more knowledgeable/ reputable and might also overestimate the fact that busy independent directors are certified as effective monitors of the banking operations and, hence, investors could anticipate subsequently high returns and high firm value.

Accordingly, published information on board busyness in Islamic banking is expected to signal to the stock market weak systems of governance and/or increased cost of equity due to high information risk. Investors are expected to perceive board busyness as leading to ineffective monitoring quality and may request higher rewards for the possibly arising risks, suggesting lower stock price multiples in Islamic banks when compared to their conventional counterparts. This prediction is in line with the good management theory (Jamali et al. 2008; Pae and Choi 2011) which states that a positive relationship between low-quality monitoring by boards and the provision of low-quality corporate-level information. This relation is likely to be pervasive when operating under opaque/complex business models. This leads to the following hypothesis, stated in the alternative form:

H1: Board busyness is significantly and highly valued by conventional banks' when compared to Islamic banks' investors. 


\subsection{Market valuations of busy SSB in Islamic banks}

Islamic banks operate on a double governance mechanism (i.e., BODs and SSB). The presence of an extra layer of governance (i.e., SSB) could serve as an effective mechanism to monitor Islamic banks' prioritisation of religious norms. The SSB's primary role is to ensure Shari'ah compliance and minimise reputation risk, which may result in capital erosion among Islamic banks as well as in lawsuits by fund providers (Archer and Karim 2007). Members of this board also serve as the counterparts of conventional internal auditors who enhance the creditability and reliability of published financial and non-financial information in the stock market (Godlewski et al. 2016). Therefore, Shari' ah governance is expected to promote investors' trust and confidence about the quality of published information by Islamic banks, who are presumably targeting investments and trades incorporate ethical and moral criteria (O'Sullivan 1996; Pomeranz 1997). Therefore, investment choices and stock price valuations are likely to be influenced by the outcomes of the screening process as well as decisions made by the SSB on the quality and sufficiency of the corporate information published by Islamic banks in compliance with the Shari'ah laws.

To date, a limited number of Shari'ah advisors engage excessively in Islamic banks' activities by sitting on many SSBs for banks operating globally (Wilson 2009; Godlewski et al. 2016). Reuters (2012) reports that the top 20 Shari' ah scholars hold about $55 \%$ of all board positions worldwide, and some scholars are much more in demand than others. As such, busy SSB can adversely affect Islamic bank investors' valuation in two ways. First, given the high concentration of the workload undertaken by a small group of Shari'ah experts and the fact that SSBs' performance is not regularly evaluated by the BODs (Mollah and Zaman 2015), SSB is expected to be less effective in their Shari' ah monitoring as a result of this such board busyness. This might signal a weak Shari' ah governance to the stock market and hence, reduce the bank value. Second, the scarcity and high reputation of Shari' ah scholars suggest that they might be expensive to appoint because their appointment reflects higher charges of salaries and remunerations which will have substantial implications on the bank financial performance leading to lower investor valuations. Prior studies suggest that expensive appoints of boards implies low-cost efficiency and poor firm performance (see Linn and Park 2005; Brick et al. 2006). This will in fact, directly affect the cost of equity and relative firm valuations in stock markets (Renneboog and Trojanowski 2011). In line with the Equity theory (Dah and Frye 2017), multiple directorships are associated with board entrenchment caused by the over-payment for those members. ${ }^{7}$

Accordingly, we conjecture that SSB busyness is likely to signal weak Shari' ah governance and low bank performance to the stock market leading to low market valuations for Islamic banks. This leads to the following hypothesis, stated in the alternative form:

H2: Islamic banks' investors negatively value busy SSB.

\footnotetext{
7 The equity theory anticipates the reaction of individuals towards over- or under-reward situations. Specifically, directors make subjective assessments of the ratio of their efforts (input) and compensation (output) to those of other referents. They may experience dissonance if their perceived ratio is unequal to that of referents. Consequently, they often reduce their efforts or try to push their compensation to obtain a similar ratio to salient other referents.
} 


\section{Data and sample}

The consolidated financial data (in U.S. dollars) are collected from DataStream, Bankscope, Thomson One Reuters, and Bloomberg databases. We hand-collected the governance data for outside directors, Shari'ah advisors and board information from banks' annual reports, corporate filings (e.g., security prospectuses or governance reports) and websites. We excluded grey directors who have personal and economic ties with the bank and management (Hsu and Wu, 2014). We followed Field et al. (2013), Fich and Shivdasani (2006) and Chakravarty and Rutherford (2017) to count for the number of directorships held by directors in all for-profit private and public firms. In other words, we excluded directorships related to activities in sports clubs, non-for-profit, trusts and charitable institutions. ${ }^{8}$ Country macroeconomics/governance indicators are retrieved from the World Bank's World Development Indicators database.

We study listed Islamic and conventional banks in global stock markets for the period 2010-2015. The selected period allows us to avoid the potential impact of the global financial crisis shock of 2007-2009. The initial sample comprises a total of 3038 banks (196 Islamic banks and 2842 conventional banks) in 36 countries. In line with prior banking studies (e.g., Beck et al. 2013; Alqahtani et al. 2017; Mollah et al. 2017), we applied the following four criteria to filter the sample: (1) The countries with both types of banks have at least two listed banks; (2) the banks have annual reports (official websites), which are published as of 31 December; (3) The full-service investment banks and banks with Islamic windows were dropped from the sample; ${ }^{9}$ and (4) The banks must have at least three consecutive years' full data availability. Our final sample is an unbalanced panel data set covering 70 listed commercial banks (386 bank-year observations) operating in 11 countries. Countries such as Malaysia and Turkey, where Islamic banks have a significant share of the total banking industry, have been excluded from the sample as most Islamic banks are not listed as separated entities on the stock markets (Saeed and Izzeldin 2016).

Table 1 presents the sample distribution by country and bank, with 27 listed Islamic banks (150 bank-year observations) and 43 listed conventional banks (236 bank-year observations). The percentage of bank representations is our sample for Islamic banks and conventional banks are reported as $38.9 \%$ and $61.1 \%$ respectively. The highest concentration of Islamic banks is found in Bahrain while Indonesia reports the highest level of conventional banks.

\footnotetext{
${ }^{8}$ For example, the 2014's annual report of Albarala Banking Group in Bahrain indicates the profile of $\mathrm{Mr}$ Abdulla Saleh Kamel (Vice Chairman of the board of directors) that is “...Mr. Abdulla Kamel has also been and remains very active in public and charitable activities through his membership of many international and local organizations and associations, such as Jeddah Chamber of Commerce (twice as Board Member), Young Presidents' Organization, Friends of Saudi Arabia, The Centennial Fund and the Board of Trustees of the Prince of Wales Business Leaders Forum." (Page 11).

${ }^{9}$ We refer to conventional banks with Islamic windows as banks with an independent department which provides Islamic products with an SSB (Elnahass et al. 2014). Our sample, following the studies of Elnahass et al. $(2014,2018)$ and Johnes et al. (2014), excludes those banks because supervisory issues and accountancy requirements are expected to be different to those of full-ledged Islamic banks (Islamic Financial Services Board 2005).
} 


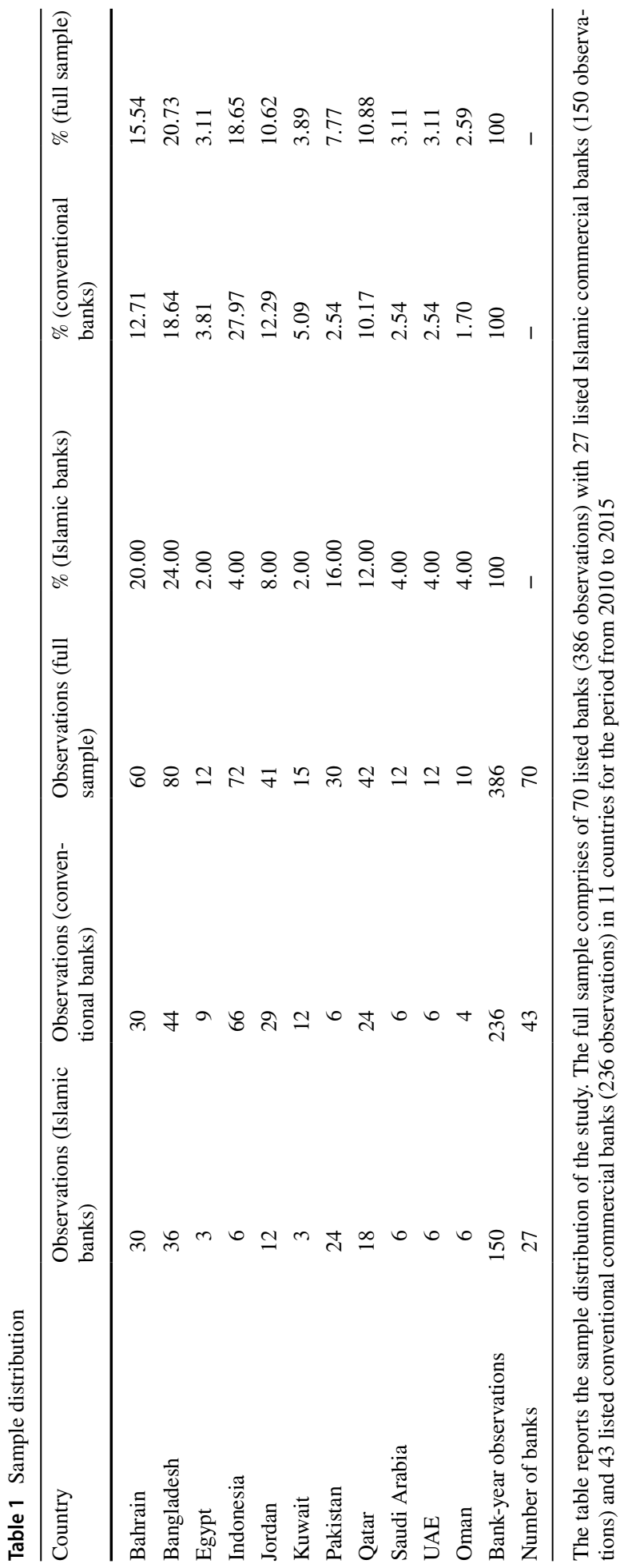




\section{Methodology}

\subsection{Measures of the bank market value}

Consistent with the prior literature, we measure the bank market value through a firmlevel market measure which is the Tobin's $q$ (hereafter, $\ln Q$ ) (e.g., Cheng et al. 2008; Ammann et al. 2011; Cashman et al. 2012; Black et al. 2015; Gyapong et al. 2016; Muravyev et al. 2016). $\ln Q$ is a forward-looking approximation of firm value that captures the value of intangible corporate resources (e.g., goodwill and trust from good board structure). It is estimated as the sum of a bank year-end book value of debt and market value of equity, divided by its year-end book value of total assets. The market value of equity is computed as the end-year number of outstanding shares multiplied by the stock prices (e.g., Busch and Hoffmann 2011; Cashman et al. 2012; Gyapong et al. 2016). Following previous studies (e.g., Black et al. 2012), we take the natural logarithm of Tobin's q to mitigate the impact of high-q outlier banks.

The selection of this measure is justified for several reasons. First, we aim to investigate the long-term firm valuations of boards' busyness. Therefore, unlike other shortterm accounting performance measures such as return on assets (ROA) or return on equity (ROE), $\ln Q$ offers long-term market valuations for a firm (e.g., Bhagat and Black 2001; Thomas and Eden 2004; Sami et al. 2011). Second, relative to $\ln Q$, ROA and ROE are likely to be subject to possible and direct earnings manipulation by management (Gyapong et al. 2016). Moreover, this measure combines the market with book values of the bank equity, distortions from tax laws and accounting conventions are minimised (Wernerfelt and Montgomery 1988). Finally, $\ln Q$ is commonly known as one of the standard dependent variables in firm value research within the context of corporate governance (Fich and Shivdasani 2006; Black et al. 2012, 2014).

\subsection{Measures of board busyness}

We define a busy board member (i.e., either BODs or SSB) as an individual who holds, at least, two outside directorships (e.g., Ferris et al. 2003; Fich and Shivdasani 2006; Cashman et al. 2012). Based on this and following Falato et al. (2014), Elyasiani and Zhang (2015), and Chou and Feng (2018), we use a standard measure of board busyness which is the percentage of busy outside directors (\%BBOD) and busy Shari'ah scholars (\%BSSB). The \%BBOD is calculated as the number of outside directors serving on two or more outside firms divided by the number of outside directors on the board. The \%BSSB is defined as the number of Shari'ah advisors serving on at least two outside organisations divided by the number of Shari'ah advisors on the board. Using the percentage of board busyness provides a plausible assessment of the board advising and monitoring intensity under the assumption of high independence, substantial contributions in the firm strategic decisions and their sound reputation maintained in the industry (Fich and Shivdasani 2006). The higher percentage of busy outside directors/Shari' ah advisors, the higher the level of busyness of BOD/SSB which influences the monitoring quality of overall board (Ferris et al. 2003; Chakravarty and Rutherford 2017). Moreover, we focus on outside directors because they are primarily responsible for scrutinising managers while insiders are potentially on BOD for many other reasons (Cashman et al. 2012). 


\subsection{Empirical models}

Banks are likely to differ in the opportunities and challenges that they may encounter over the years due to the peculiar nature of their sector. This can lead to a situation where disclosure of board directorships, other board characteristics and bank market value are jointly and dynamically determined by unobserved bank-specific variables (e.g., quality and style of management, business strategy, market perception and bank complexity) (Henry 2008; Guest 2009), which pooled ordinary least square (OLS) estimation may detect and control (Kraatz and Zajac 2001; Wooldridge 2002). Therefore, we employ panel data estimations to mitigate endogeneity problems arising from potential unobserved bank-specific heterogeneity (e.g., Henry 2008; Guest 2009). Although better governance practices of a firm can enhance its profitability position, investors' valuation may only be capturing the high profitability performance rather than perceiving the specific board busyness attribute. To overcome possible misinterpretations of the investors' firm valuations, we include a comprehensive set of control variables to mitigate omitted-variable bias as well as utilised three-stage least-square (3SLS) estimations with instrumental variables (IVs) (e.g., Bhagat and Black 2001; Coles et al. 2008; Faleye et al. 2011) to mitigate the endogeneity between busy boards and bank valuation. ${ }^{10}$

The choice of valid IVs implies a correlation with the endogenous variable, and not with the error terms of the dependent variable ${ }^{11}$ (Elyasiani and Jia 2008). Consistent with Elyasiani and Zhang (2015), we use the number of public firms headquartered in the same country of the bank as our first IVs (source: World Bank). We contend that outside directors of the bank headquartered in countries with more public firms are more likely to find additional jobs in other companies. We, therefore, expect that the number of busy outside directors is positively related to the number of public firms headquartered in the same country. The other IVs employed for board busyness is the country-level income generating category (Source: World Bank). This variable takes a value of 1 if the "home" bank is in a middle and high-income generating nation, and 0 otherwise. ${ }^{12} \mathrm{We}$ argue that directors of banks headquartered in the high-income countries with more skill-job opportunities are more likely to find director positions in other institutions (Goldberg and Pavcnik 2007; World Bank 2016). This might positively affect the number of the directorships by outside boards.

Both IVs are correlated with possible endogenous variables (i.e., \%BBOD; \%BSSB) and should predict stock market valuations only indirectly, through their effects on endogenous variables (see Black et al. 2006). Indeed, in our study setting and sampled banks, those IVs can indirectly affect bank valuations because the country-level indicators are less likely to

\footnotetext{
10 The Wu-Hausman endogeneity test (e.g., Wu 1973; Hausman 1978) statistics reveal the presence of endogeneity biases.

11 Two diagnostic tests are performed to examine both IVs' and the specification of our system equations' validity. First, we present the Sargan test which shows the misspecification test with the null hypothesis of no misspecification. We then report the second test (Breusch and Pagan LM) to investigate whether crossequation disturbances are truly related and if the equations will need to be tested simultaneously. These statistics suggest that both IVs theoretically and statistically satisfy the necessary conditions for validity and relevance, and thus, findings obtained by 3SLS is more consistent and efficient than those of traditional pooled OLS.

12 World Bank (2015) classifies countries as middle and high income if their Gross National Income (GNI) per capita is more than $\$ 1045$. By contrast, countries are categorised as low-income if their GNI per capita is $\$ 1045$ or less in 2014 .
} 
influence Tobin's q endogenously. We, accordingly, specify the simultaneous models as follows:

$$
\begin{aligned}
& \ln Q_{i t}=\beta_{0}+\beta_{1} \% B B O D_{i t}+\phi P+\mu \text { Year effects }+\pi \text { Bank effects }+\varepsilon_{i t} \\
& \% B B O D_{i t}=\beta_{0}+\beta_{1} \ln Q_{i t}+\phi P+\mu \text { Year effects }+\pi \text { Bank effects }+\varepsilon_{i t}
\end{aligned}
$$

where $\ln Q_{i t}$ represents the natural logarithm of Tobin's q for bank $i$ at time $t$; \%BBOD represents the percentage of busy outside directors; $\phi P$ is a vector of control variables in the bank valuation model. $\varepsilon_{i t}$ is the error term.

Our control variables include board size (LnBSIZE) to control for the boards' role and effectiveness. This variable is calculated by the natural logarithm of the number of board members (Cheng et al. 2008; Mollah and Zaman 2015; Faleye and Krishnan 2017). We further control for the board independence $(\% I N D E P)$, which is measured by the percentage of outside non-executive directors on board, respectively (Cashman et al. 2012; Li 2014; Boateng et al. 2017; DeBoskey et al. 2019). We also control for bank size (LogTA) by using the natural logarithm of total assets measured in thousands of USD of a bank at the end of the fiscal year (Black et al. 2012; Chen et al. 2018). We also include financial leverage $(L E V)$, measured by the ratio of total liability over total equity, because leverage can affect $\ln Q$ through tax benefits and mitigation of free cash flow problems (Black et al. 2012; Cheng et al. 2006; Black and Kim 2012). We also control for Big4 auditor (BIG4) taking a value of 1 when the bank has a big4 auditor and 0 otherwise (Mollah and Zaman 2015). We further follow the prior research on governance (e.g., Aggarwal et al. 2009; Ammann et al. 2011; Luo and Hachiya 2005) to control for the ratio of cash to total assets (CASH/ASSETS) and the ratio of capital expenditure to total assets (CAPEX/ASSETS). Following Mollah et al. (2017) and Chang et al. (2018), we control for the possible effect of banking sector concentration on value by using the Herfindahl-Hirschman Index ( $H H I)$.

Moreover, we control for differences in economic development across countries by adding the GDP per capita (GDPCAPITA). We finally capture between-country differences in governance perceptions by introducing a country governance index (COUNTRY_GOV) (Kaufmann et al. 2005; Čihák and Hesse 2010). This variable is estimated as the average of six governance measures including the regulatory quality, the rule of law, control of corruption, political stability, governance effectiveness, and the voice and accountability. This index captures cross-country differences in institutional developments that are expected to have an impact on banking market value. We predict that investors are more likely to invest their capital in the stock market in countries with higher COUNTRY_GOV. In other words, the higher the index, the higher the bank value.

We control for both year and bank fixed effects in all models. For the treatment of the outliers, we winsorise each variable in our test models at the 1st and 99th percentiles. Table 2 presents variable definitions and notations in our estimated models.

\subsection{Descriptive statistics}

Table 3 reports the descriptive statistics for the full sample and the banks' subsamples of Islamic banks (IBs) and conventional banks $(\mathrm{CBs})$. With regards to the bank market value, we find that IBs report a higher mean of $\ln Q(0.259)$ than that of CBs (0.220). However, the two-sample $t$ test shows an insignificant difference between these two sub-samples. For the governance indicators, the full sample reports an average level of board busyness which is $48 \%$ for the BODs (\%BBOD). IBs show a lower mean of $\% B B O D$ of $43 \%$ while CBs report $51 \%, t$ test show significant mean differences between the two bank types' board 


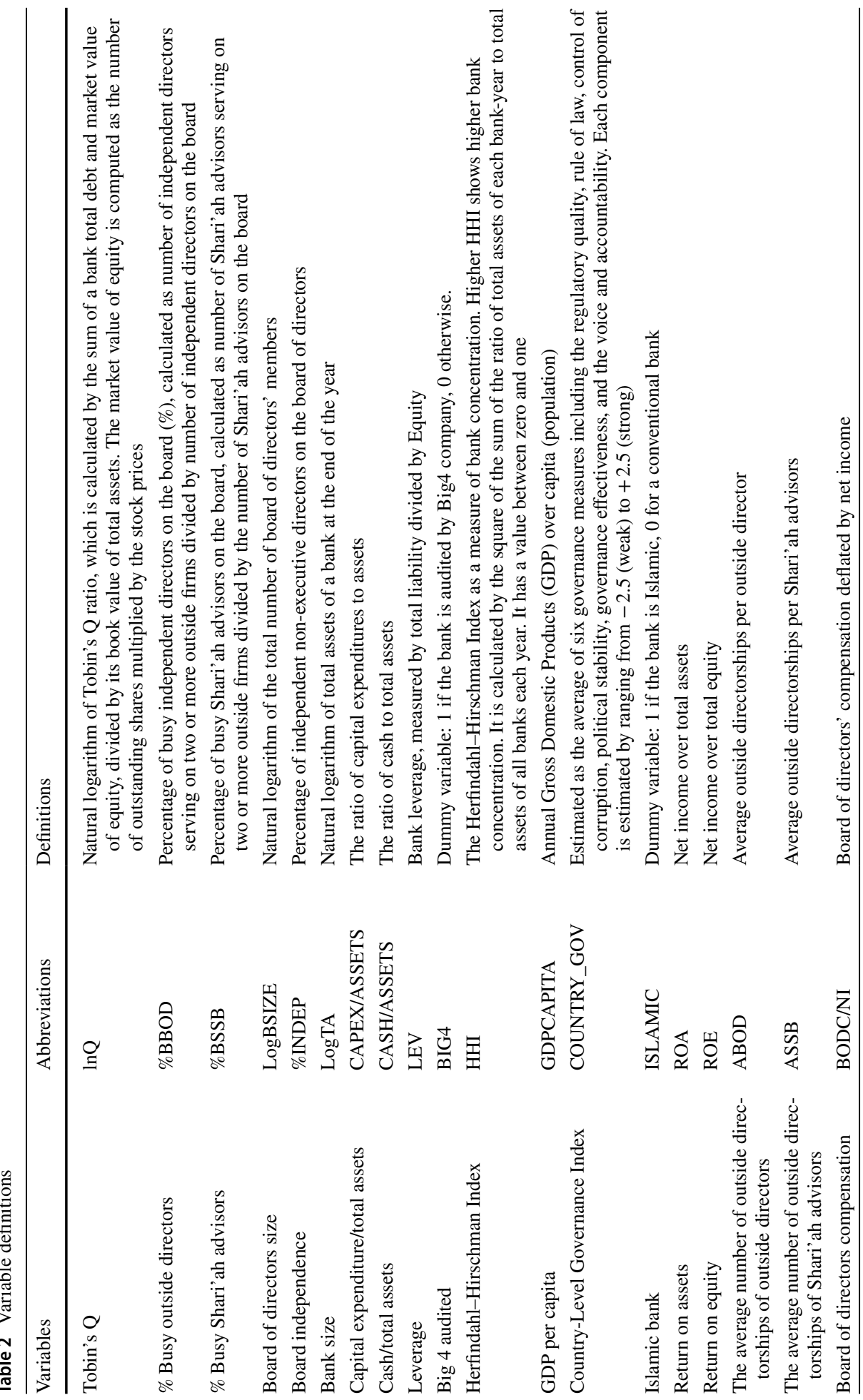




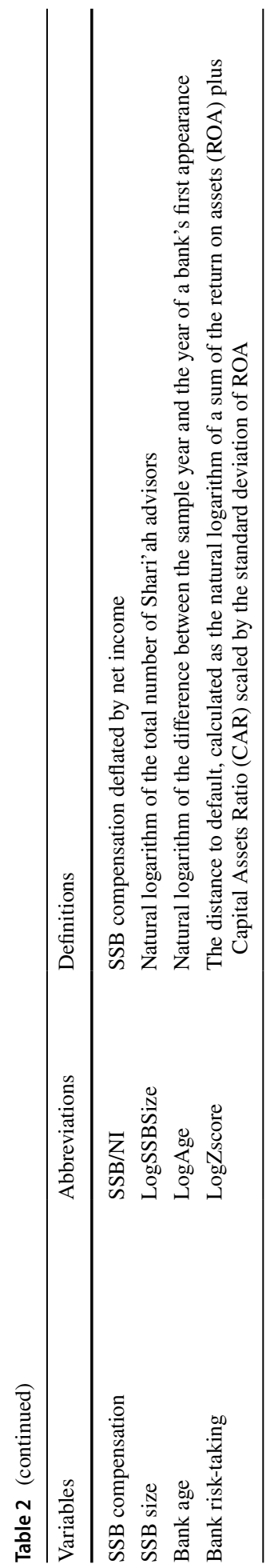




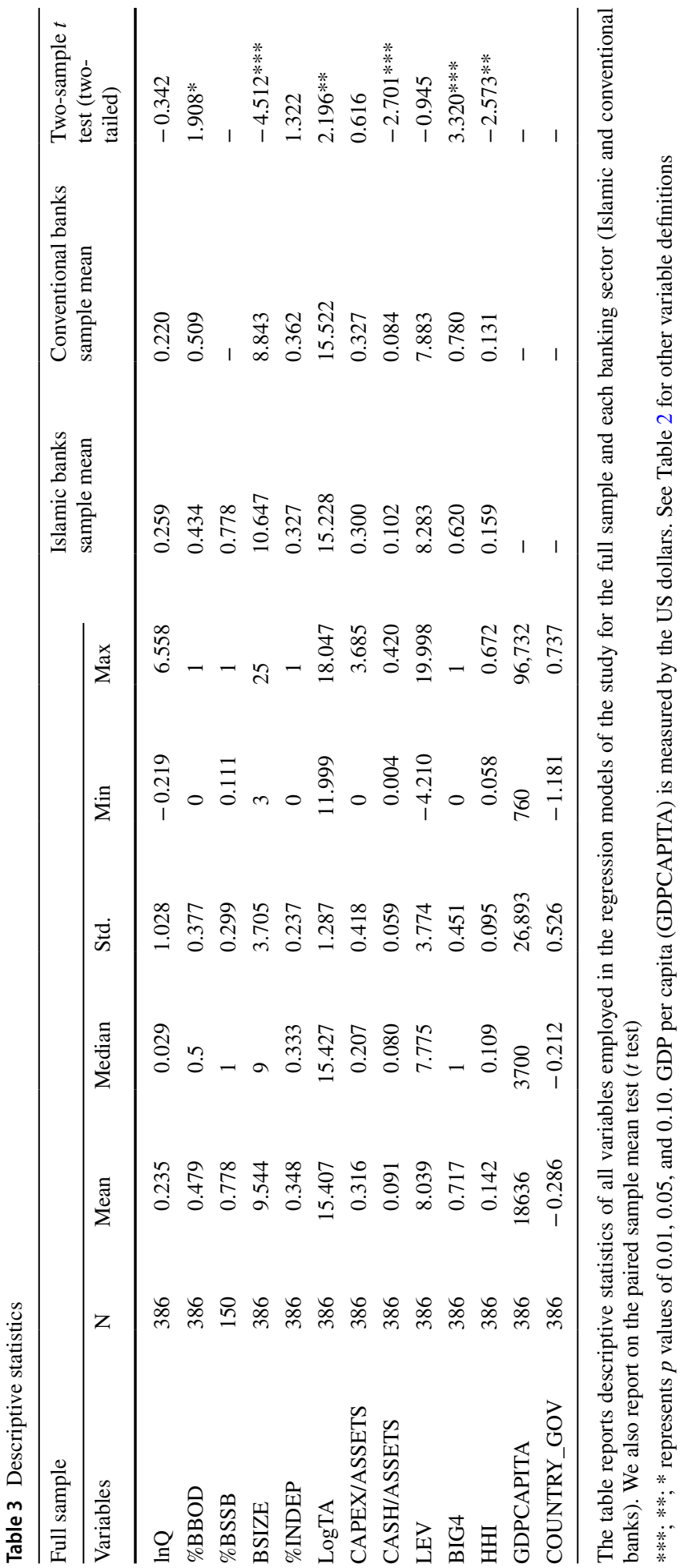


busyness. For SSB busyness (\%BSSB), the IBs subsample reports that SSB has a substantially high level of busyness with a mean of $77.78 \%$. Moreover, IBs show significantly larger board size (11 directors) relative to CBs ( 9 directors). For board independence, on average, IBs (CBs) report 33\% (36\%) respectively, with an insignificant difference between the two bank types.

Consistent with prior literature (e.g., Elnahass et al. 2018), our finding suggests that IBs are significantly smaller in firm size $(\log T A)$ than CBs. Finally, we find that IBs have significantly higher cash to total assets ratio (CASH/ASSETS) than CBs. This result indicates that IBs are more likely to hold cash in response to the arising liquidity management challenges under their constrained banking model.

We present the Pearson pair-wise correlation matrix of all independent variables for both sub-samples of IBs and CBs in Table 4 (Panel A and B). The results show accepted correlation coefficients (i.e., smaller than 0.8 ), which suggest that there are no serious concerns for multicollinearity. This is also supported by the unreported low individual VIF values $(<10)$, low means of VIFs $(<6)$ and low condition numbers $(<15)$ for all the test variables.

\section{Empirical results}

\subsection{Market valuations of busy boards of directors in Islamic and conventional banks}

Table 5 reports the three-stage least square (3SLS) estimations examining the effect of board busyness on market valuations for the full sample (Panel A), IBs (Panel B, BOD: column 1; and SSB: column 2) and CBs (Panel C) subsamples.

For the full sample, in Panel A, the coefficient on BOD busyness $(\% B B O D)$ is significantly and positively associated with $\ln Q$. This implies that investors, on average, perceive board busyness as value-enhancing board attribute that increases bank valuations. This result is in line with, both, the resource dependence and signalling theories suggesting that outside directors serving on many boards can promote strong governance and bring strategic resources (e.g., extended industry knowledge, expertise and access to market sources) to their firms and hence, positively valued by investors. With respect to the control variables, board size ( $\log B S I Z E)$ shows a negative and significant coefficient, which is consistent with prior evidence predicting that small boards tend to perform more effectively than large boards (e.g., Yermack 1996; Eisenberg et al. 1998; Abbott et al. 2004; Gyapong et al. 2016). ${ }^{13}$ The coefficient on board independence (\%INDEP) is negative and significant which suggests that more outside directors serving on many boards are associated with lower firm valuations (Ararat et al. 2010; Black et al. 2012). Moreover, higher cash reserves tend to be associated with lower market valuations, as represented by the negative and significant coefficient on CASH/ASSETS ratios. These findings are in line with Ammann et al. (2011). Results further show negative associations between $\ln Q$ and BIG4. The low valuation for Big4 firms might be attributable to investors' perception that Big 4 is

\footnotetext{
13 Having a small board associated with high financial ratios (e.g., profitability and operating efficiency) and better CEO compensation. As a result, some empirical evidence (e.g., Kini et al. 1995; Yermack 1996) indicate that small boards are preferred by institutional investors, dissident directors and corporate raiders.
} 


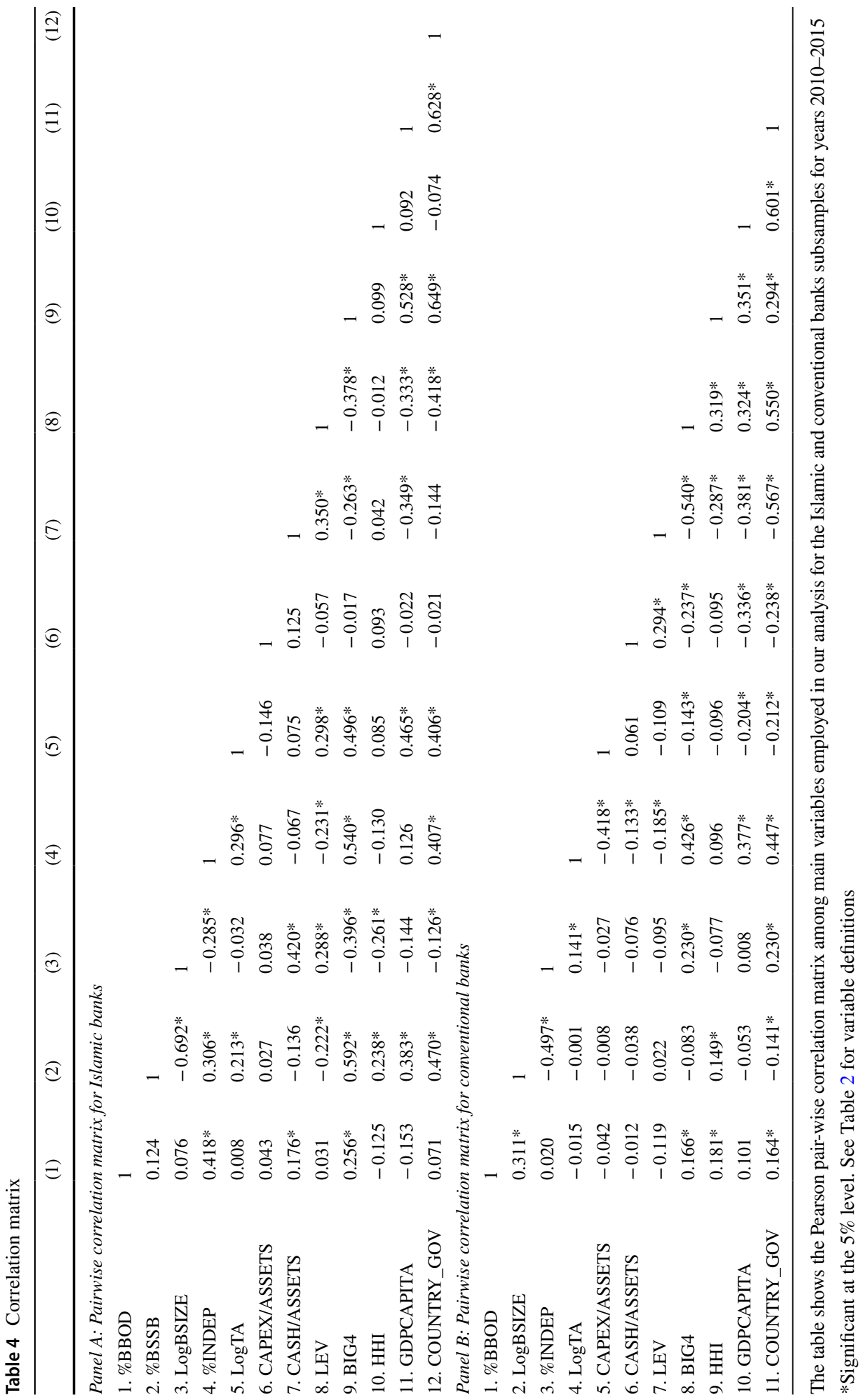


Table 5 Boards busyness and bank valuation—within Islamic and conventional banks

\begin{tabular}{|c|c|c|c|c|}
\hline \multirow[t]{2}{*}{ Variables } & \multirow{2}{*}{$\begin{array}{l}\text { Panel A: Full sam- } \\
\text { ple (IBs and CBs } \\
\text { together) } \\
\ln Q \\
(1)\end{array}$} & \multicolumn{2}{|c|}{ Panel B: Islamic banks (IBs) } & \multirow{2}{*}{$\begin{array}{l}\text { Panel C: Conven- } \\
\text { tional banks (CBs) } \\
\ln Q \\
(4)\end{array}$} \\
\hline & & $\begin{array}{l}\ln Q \\
(2)\end{array}$ & $\begin{array}{l}\ln Q \\
(3)\end{array}$ & \\
\hline$\%$ BBOD & $2.950 * * *(0.000)$ & $0.285(0.109)$ & $0.427(0.104)$ & $1.826 * * *(0.000)$ \\
\hline$\% \mathrm{BSSB}$ & & & $-1.365^{* * *}(0.007)$ & \\
\hline LogBSIZE & $-0.391 * * *(0.004)$ & $-0.117 *(0.096)$ & $-0.159 *(0.084)$ & $0.152(0.192)$ \\
\hline INDEP & $-1.006^{* * *}(0.000)$ & $-0.233^{* * *}(0.004)$ & $-0.347 * * *(0.004)$ & $-0.786^{* * *}(0.000)$ \\
\hline $\log \mathrm{TA}$ & $0.048(0.643)$ & $0.048 *(0.087)$ & $0.129 * *(0.050)$ & $-0.278 * * *(0.003)$ \\
\hline CAPEX/ASSETS & $0.003(0.561)$ & $0.002(0.420)$ & $0.005(0.100)$ & $-0.002(0.745)$ \\
\hline CASH/ASSETS & $-2.045 * * *(0.000)$ & $-0.713 * * *(0.007)$ & $-0.673 * *(0.036)$ & $-1.349 * * *(0.007)$ \\
\hline LEV & $-0.004(0.719)$ & $0.012 * *(0.049)$ & $0.017 * *(0.047)$ & $0.010(0.405)$ \\
\hline BIG4 & $-0.617 * * *(0.002)$ & $-0.147 *(0.094)$ & $-0.223 *(0.094)$ & $-0.333 * * *(0.009)$ \\
\hline HHI & $0.446(0.125)$ & $-0.015(0.869)$ & $0.177(0.190)$ & $0.524(0.131)$ \\
\hline GDPCAPITA & $-0.014 * * *(0.005)$ & $0.005 * *(0.011)$ & $0.003(0.339)$ & $-0.008 * *(0.040)$ \\
\hline COUNTRY_GOV & $0.496 * *(0.033)$ & $-0.028(0.812)$ & $0.042(0.777)$ & $0.395 * *(0.034)$ \\
\hline ISLAMIC & $0.091(0.735)$ & & & \\
\hline Constant & $0.465(0.769)$ & $-0.350(0.581)$ & $-0.247(0.808)$ & $3.379 * *(0.025)$ \\
\hline Year fixed effect & YES & YES & YES & YES \\
\hline Bank fixed effect & YES & YES & YES & YES \\
\hline Observations & 386 & 150 & 150 & 236 \\
\hline Adjusted $\mathrm{R}^{2}$ & 0.748 & 0.994 & 0.990 & 0.882 \\
\hline $\begin{array}{l}\mathrm{Chi}^{2} \\
\text { LM statistics ( } p \\
\quad \text { value) }\end{array}$ & $\begin{array}{l}3164 * * * \\
0.000 \\
0.414\end{array}$ & $\begin{array}{l}2645 * * * \\
0.046 \\
0.151\end{array}$ & $\begin{array}{l}1423 * * * \\
0.000 \\
0.199\end{array}$ & $\begin{array}{l}4480 * * * \\
0.000 \\
0.376\end{array}$ \\
\hline Sargan test ( $p$ value) & & & & \\
\hline $\begin{array}{l}\% B B O D=\% B S S B \\
(F \text {-test })\end{array}$ & & & 0.000 & \\
\hline
\end{tabular}

The table presents three-stage least-square (3SLS) results for the full sample (Panel A), Islamic bank subsample (Panel B) and conventional bank subsample (Panel C) identifying the effect of busy board of directors or busy SSB on a bank's firm value. We build simultaneous equations models

$\ln Q_{i t}=\beta_{0}+\beta_{1} \% B B O D_{i t}+\phi P+\mu$ Year effects $+\pi$ Bank effects $+\varepsilon_{i t}$

$\% B B O D_{i t}=\beta_{0}+\beta_{1} \ln Q_{i t}+\phi P+\mu$ Year effects $+\pi$ Bank effects $+\varepsilon_{i t}$

Where, $\phi \mathrm{P}$ is a vector of control variables in the bank valuation model including bank-level indicators, country-level indicators, and country governance indicators. Models are tested for the period of 6-year from 2010. The diagnostic tests show that LM statistics $p$ value is less than $1 \%$ and Sargan test $p$ value is greater than $10 \%$ across all models, indicating that the chosen IVs for board of directors' busyness are valid and the models are not over-identified

$p$ values in parentheses, $* p<0.10 ; * * p<0.05$; *** $p<0.01$. ISLAMIC is a dummy indicator for Islamic banks which takes the value of 1 if the bank is Islamic, 0 for conventional banks. See Table 2 for other variable definitions

either more expensive to appoint (Craswell et al. 2002) or offer similar quality of assurance services to those provided by non-Big4 firms (Lawrence et al. 2010). Finally, the significant and positive coefficient on COUNTRY_GOV suggests that higher country governance is associated with investors' valuations. 
When examining the effect of the BOD busyness across the two bank types, in Table 5, we find insignificant evidence for the effect of busy outside directors on the market valuations for IBs (in Panel B, column 1). This implies that investors in IBs seem not to price board busyness. For CBs (in Panel C), we find a positive association between $\% B B O D$ and $\ln Q$, suggesting that investors in $\mathrm{CBs}$ tend to perceive board busyness increases the firm value significantly. The coefficient of busy BOD in CBs is also economically significant, as a one per cent increase in board busyness reflects an increase in the bank value by 182.6 per cent. Results for the controls across the two bank types are generally consistent with the main findings of the full sample. However, we find a positive association between the bank size $(\log T A)$ and $\ln Q$ for IBs, which implies that large IBs are more likely to experience higher market valuation than small IBs. The result may be justified by large IBs maintain higher quality financial reporting and stronger governance mechanisms. In contrast, such a relationship is significantly negative in $\mathrm{CBs}$, indicating lower pricing by investors of CBs for larger banks. These findings are consistent with prior studies (Elnahass et al. 2014, 2018).

Taken together, our findings show that board busyness has a differential effect on the market valuations across both bank types. Busy board increases the market valuations for CBs with no significant evidence for IBs which is in line with our prediction and supports our first hypothesis $H_{1}$. The positive effect of board busyness on the market valuations of CBs indicates that some reputational benefits are likely to dominate investors' expectations. The emerging reputational benefits from board busyness seem to alleviate investors' uncertainty related to ineffective monitoring and agency conflicts between investors and bank managers. This, in turn, leads to high market valuations. Our finding is consistent with prior literature within the industrial sector settings (e.g., Ammann et al. 2011; Field et al. 2013; Clifford et al. 2017). The absence of market valuations for IBs can be justified through the signalling theory. Investors in IBs seem to be well informed about the importance of effective monitoring as well as the relative implications of poor Shari'ah governance. These findings suggest that investors seem to be sceptical of board busyness and penalise IBs by not valuing busy outside directors, which is in line with the busyness view.

\subsection{Market valuations of busy SSB in Islamic banks}

We extend our analyses to test $H_{2}$ expecting negative market valuations for busy SSB in IBs. In Table 5 (Panel B, column 2), results show a negative and significant coefficient on \%BSSB which suggests that SSB busyness reduces bank value. The coefficient on SSB busyness is also economically significant; one per cent increase in SSB busyness, on average, is associated with a decrease in the market value of IBs by 136.5 per cent. Results for other control variables remain qualitatively unchanged. Busy BODs show an insignificant impact on IBs valuations consistently. To examine whether there is a significant difference between the two-board busyness (BOD versus SSB) results, we compare the coefficients on \%BBOD and \%BSSB. The reported F-test (i.e., Wald test) indicates that the two coefficients are statistically different.

Overall findings imply that investors seem to discount the value of IBs appointing busy SSB possibly because such busyness could jeopardise their responsibilities and commitments in screening out the bank activities/transactions to emphasis on their Shari' ah compliance. Moreover, investors seem to differentially perceive busyness of SSB and BOD, placing substantial valuation for busy SSB only. This might be justified by the relative high 
trust and confidence that effective Shari'ah monitoring could have in preserving the religious/ethical orientation of this banking sector (Elnahass et al. 2018).

\section{Additional testing}

\subsection{Tests for the effect of busy boards on bank agency relationships}

High market valuations in banking are likely to be affected by the level of agency costs. Board busyness could exacerbate agency costs because a busy board will have less time, effort and attention to fulfil their roles and to effectively monitor which could affect market valuations. In this section, we additionally examine whether busy BOD can either diminish or exacerbate bank agency costs across IBs and CBs. To do so, we build simultaneous equation models, which are specified in Eq. 3 and 4 as bellows:

$$
\begin{aligned}
& \text { CASH } / \text { ASSETS }_{i t}=\beta_{0}+\beta_{1} \% B B O D_{i t}+\phi P+\mu \text { Year effects }+\pi \text { Bank effects }+\varepsilon_{i t} \\
& \% B B O D_{i t}=\beta_{0}+\beta_{1} C A S H / \text { ASSETS }_{i t}+\phi P+\mu \text { Year effects }+\pi \text { Bank effects }+\varepsilon_{i t}
\end{aligned}
$$

where $C A S H / A S S E T S_{i t}$ represents bank agency relationships, measured by the ratio of cash to total assets (see Farag et al. 2018) and a higher ratio indicates more agency costs. We include a comprehensive set of controls which can explain for the firm agency costs, such as board size ( $\log B S I Z E)$, board independence (\%INDEP), firm size (LogTA), firm age (LogAge), firm risk-taking (LogZscore), and firm profitability (ROAA) computed by the ratio of net income to average total assets. GDP per capita (GDPCAPITA) and country governance index (COUNTRY_GOV). For IBs subsample, we also include SSB busyness (\%BSSB) and SSB size (LogSSBSize) measured by the natural logarithm of the number of Shari'ah scholars serving on SSB. This is consistent with Farag et al. (2018).

Table 6 (Panel A and B) shows that there are differential impacts of board busyness on agency costs across IBs and CBs. Conditional on the bank type, busy BOD is significantly and negatively associated with agency costs in CBs (i.e., lower agency costs). IBs show significantly high agency costs associated with busy boards. This can be attributable to the constrained business model of IBs which requires extended monitoring to protect the minority rights of investment account holders/depositors' who engage with the bank under the profit and loss sharing arrangements. Therefore, BOD busyness is less likely to reduce the agency conflicts within this bank model.

Furthermore, in Table 6 (Panel A), we find that \%BSSB has a positive and significant relationship with CASH/ASSETS. This confirms that the agency conflicts within IBs are also severe when those banks employ a busy SSB member(s). Therefore, lower market valuations for IBs can be partly explained by higher agency costs arising from appointing a busy SSB. The reported F-test (i.e., Wald test) shows that the coefficients of $\% B B O D$ and $\% B S S B$ are statistically differential.

\subsection{Tests for the influence of boards compensation on busyness}

In the main result section, we argued that the scarcity and high reputation of Shari'ah scholars would imply that they are expensive to appoint and could result in lower cost 
Table 6 The effects of boards busyness on agency relationships—within Islamic and conventional banks

\begin{tabular}{|c|c|c|}
\hline \multirow[t]{2}{*}{ Variables } & Panel A: Islamic banks (IBs) & $\begin{array}{l}\text { Panel B: Conven- } \\
\text { tional banks (CBs) }\end{array}$ \\
\hline & $\begin{array}{l}\text { CASH/ASSETS } \\
\text { (1) }\end{array}$ & $\begin{array}{l}\text { CASH/ASSETS } \\
\text { (2) }\end{array}$ \\
\hline$\% \mathrm{BBOD}$ & $0.033 *(0.091)$ & $-0.099 * * *(0.000)$ \\
\hline$\%$ BSSB & $0.211 * *(0.030)$ & \\
\hline LogBSIZE & $0.008(0.733)$ & $-0.010(0.514)$ \\
\hline$\%$ INDEP & $-0.041 *(0.097)$ & $0.020(0.290)$ \\
\hline LogTA & $0.046 * *(0.022)$ & $0.024 *(0.084)$ \\
\hline LogAge & $-0.056^{* *}(0.047)$ & $-0.016(0.476)$ \\
\hline LogZscore & $-0.043 * *(0.021)$ & $0.026 *(0.081)$ \\
\hline ROAA & $-0.001(0.857)$ & $0.012 *(0.061)$ \\
\hline GDPCAPITA & $0.003(0.859)$ & $-0.001 * * *(0.004)$ \\
\hline COUNTRY_GOV & $0.003(0.933)$ & $0.053 *(0.056)$ \\
\hline LogSSBSize & $0.068 *(0.080)$ & \\
\hline Constant & $-0.512(0.232)$ & $-0.321(0.241)$ \\
\hline Year fixed effect & YES & YES \\
\hline Bank fixed effect & YES & YES \\
\hline Observations & 150 & 236 \\
\hline Overall $\mathrm{R}^{2}$ & 0.804 & 0.543 \\
\hline Wald $\mathrm{Chi}^{2}$ & $700 * * *$ & $463 * * *$ \\
\hline LM statistics ( $p$ value) & 0.000 & 0.000 \\
\hline Sargan test ( $p$ value) & 0.765 & 0.832 \\
\hline$\% B B O D=\% B S S B(F$-test $)$ & 0.002 & \\
\hline
\end{tabular}

This table reports the 3SLS estimation results on the effect of the busy boards (busy BOD and/or busy SSB) on bank agency costs for Islamic banks (Panel A) and conventional banks (Panel B). Our model is specified as follows

CASH $/$ ASSETS $_{i t}=\beta_{0}+\beta_{1} \% B B O D_{i t}+\phi P+\mu$ Year effects $+\pi$ Bank effects $+\varepsilon_{i t}$

$\% B B O D_{i t}=\beta_{0}+\beta_{1} C A S H /$ ASSETS $_{i t}+\phi P+\mu$ Year effects $+\pi$ Bank effects $+\varepsilon_{i t}$

Where CASH/ASSETS ${ }_{i t}$ represents agency costs within banks, which is calculated by the ratio of cash divided by total assets

$p$ values in parentheses, ${ }^{*} p<0.10 ; * * p<0.05 ; * * * p<0.01$. See Table 2 for variable definitions

efficiencies. To examine this argument, we conduct additional examinations for the effects of the BODs/SSBs compensation on their busyness for both IBs and CBs. The compensation variable is defined as the ratio of board total compensation (i.e., the sum of annual directors' fixed fees like salaries, meeting and committee fees, bonus, and in-kind benefits) to the firm's net income (see Jensen and Murphy, 1990). Our regressions models employ OLS with robust standard errors and specified in Eqs. 5 and 6 as follows:

$$
\begin{gathered}
\% B B O D_{i t}=\beta_{0}+\beta_{1} B O D C / N I_{i t}+\phi P+\mu \text { Year effects }+\varepsilon_{i t} \\
\% B S S B_{i t}=\beta_{0}+\beta_{1} S S B C / N I_{i t}+\phi P+\mu \text { Year effects }+\varepsilon_{i t}
\end{gathered}
$$

where $B O D C / N I_{i t}$ represents the ratio of BOD compensation to net income. $S S B C / N I_{i t}$ represents the ratio of SSB compensation to net income. Control variables include LogBSIZE, 
Table 7 Effects of boards compensation on boards busyness-within Islamic and conventional banks

\begin{tabular}{|c|c|c|c|c|}
\hline \multirow[t]{2}{*}{ Variables } & \multirow{2}{*}{$\begin{array}{l}\text { Panel A: Full sample } \\
\text { (IBs and CBs together) } \\
\% B B O D \\
\text { (1) }\end{array}$} & \multicolumn{2}{|c|}{ Panel B: Islamic banks (IBs) } & \multirow{2}{*}{$\begin{array}{l}\text { Panel C: Con- } \\
\text { ventional banks } \\
\text { (CBs) } \\
\% B B O D \\
(4)\end{array}$} \\
\hline & & $\begin{array}{l}\% B B O D \\
\text { (2) }\end{array}$ & $\begin{array}{l}\% B S S B \\
\text { (3) }\end{array}$ & \\
\hline $\mathrm{BODC} / \mathrm{NI}$ & $-0.155^{* *}(0.024)$ & $0.345(0.376)$ & & $-0.131 * *(0.049)$ \\
\hline $\mathrm{SSBC} / \mathrm{NI}$ & & & $0.454 * *(0.019)$ & \\
\hline LogBSIZE & $0.381 * * *(0.000)$ & $0.225 * *(0.015)$ & $-0.115 * * *(0.007)$ & $0.470 * * *(0.000)$ \\
\hline$\%$ INDEP & $0.576^{* * *}(0.000)$ & $0.706 * * *(0.000)$ & $0.184 * * *(0.000)$ & $0.480 * * *(0.000)$ \\
\hline ROAA & $-0.007(0.239)$ & $-0.005(0.531)$ & $-0.008 * * *(0.003)$ & $0.005(0.797)$ \\
\hline LogTA & $-0.031 *(0.068)$ & $-0.010(0.727)$ & $0.011(0.383)$ & $-0.042 * *(0.037)$ \\
\hline GDPCAPITA & $0.001(0.304)$ & $-0.002 * * *(0.010)$ & $0.001 * *(0.038)$ & $0.002 * *(0.017)$ \\
\hline ISLAMIC & $-0.144 * * *(0.000)$ & & & \\
\hline LogSSBSize & & & $-0.470 * * *(0.000)$ & \\
\hline Constant & $-0.032(0.901)$ & $-0.154(0.717)$ & $1.529 * * *(0.000)$ & $-0.044(0.893)$ \\
\hline Year fixed effect & YES & YES & YES & YES \\
\hline Bank fixed effect & YES & YES & YES & YES \\
\hline Observations & 386 & 150 & 150 & 236 \\
\hline Overall $\mathrm{R}^{2}$ & 0.168 & 0.262 & 0.793 & 0.177 \\
\hline Wald $\mathrm{Chi}^{2}$ & $11 * * *$ & $17 * * *$ & $94 * * *$ & $7 * * *$ \\
\hline
\end{tabular}

The table presents the OLS regression results for the impacts of boards (BOD/SSB) compensation on their busyness for the full sample (Panel A), Islamic banks (Panel B) and Conventional banks subsamples (Panel C) for years 2010-2015. Our model is specified as follows

IBs/CBs subsample: $\% B B O D_{i t}=\beta_{0}+\beta_{1} B O D C / N I_{i t}+\phi P+\mu$ Year effects $+\varepsilon_{i t}$

IBs subsample: $\% B S S B_{i t}=\beta_{0}+\beta_{1} S S B C / N I_{i t}+\phi P+\mu$ Year effects $+\varepsilon_{i t}$

Compensation of BOD/SSB (BODC/NI; SSBC/NI) is computed as the percentage of net income

Robust standard errors $p$ values in parentheses, * $p<0.10 ; * * p<0.05 ; * * * p<0.01$

\%INDEP, ROAA, LogTA, GDPCAPITA, and LogSSBSize. For the full sample, ISLAMIC is also included.

Table 7 presents the results for the full sample (Panel A), IBs (Panel B) and CBs (Panel C). We find that for the full sample (Panel A), the coefficient on BODC/NI is significant and negative, implying that BOD busyness is negatively related to board compensation. A similar result is observed for CBs (Panel B), which suggests that low board compensation is a significant determinant for outside directors' busyness in CBs. However, this effect is not evidential in IBs due to an insignificant coefficient on BODC/NI (Panel B, column 1).

Furthermore, in Panel B (column 2), we find a significant and positive association between $S S B C / N I$ and $\% B S S B$. The result provides strong evidence for the main findings that employing busy Shari' ah advisors is expensive to appoint. This may further explain our main results for the low bank value for IBs with busy SSB. 


\section{Sensitivity and robustness checks}

\subsection{Propensity score matching approach}

Methodological problems such as self-selection bias regarding the endogeneity of the busyness could arise when investigating the association between board busyness and market valuations due to several reasons. First, comparing between banks having busy boards with other banks with no busy boards might yield biased estimates of the board busyness because the market value of the latter may differ systematically from the value of the former in the absence of busyness. Thus, if banks with busy boards are found to be priced higher, on average, than banks with non-busy boards, the difference could be due to differences in banks' characteristics prior to having busy boards. Secondly, considering only banks with busy boards reduces the possibility of having a hypothetical benchmark (i.e., the market value of banks with non-busy boards). Additionally, the observed change in market valuation could be resulting from shocks influencing all banks equally regardless of the busyness board attribute. To overcome these issues, the propensity score matching (PSM) method can be utilised as a popular non-parametric approach for estimating causal effects (Casu et al. 2013). We apply the PSM approach to gauge the causal relationship between board busyness and bank market value. The board busyness is considered as the treatment, the banks having busy boards as the group of treated units, and the banks having non-busy boards as the group of non-treated units. Accordingly, we define: (1) a treatment (i.e., if a board is involved in multiple-directorship), (2) a group of treated units (i.e., banks with busy boards), and (3) a group of non-treated units as a control group (i.e., banks with non-busy boards) (see Caliendo and Kopeinig 2008).

We follow the research design of Casu et al. (2013) and implement the PSM method through 3 steps: (1) estimating propensity scores for the banks having busy boards and banks having non-busy boards, (2) matching banks having busy boards with those having non-busy boards, and finally, (3) estimating average board busyness effects. To estimate the propensity scores, we employ a probit regression of a dummy variable that has a value of one for the bank-year observations with busy boards (i.e., the fraction of busy outside directors serving on BODs is at least 50 per cent) and zero otherwise. The main aim of this test is not to predict the treatment, but to balance all the covariates between the two groups (Caliendo and Kopeinig 2008). Given that all control variables (i.e., BODC/NI; LogBSIZE; \%INDEP; ROAA; LogTA; GDPCAPITA; COUNTRY_GOV; ISLAMIC) included in the propensity score model should not be impacted by the treatment; hence, they are lagged by 1 year which is in line with Casu et al. (2013). After having estimated the propensity scores of board busyness, we proceed to match banks having busy boards with those having nonbusy boards. We use the nearest-neighbor matching approach where the unit chosen from the banks with non-busy boards as a match for the banks having busy boards, the one closest in terms of the propensity score. Distribution of the Propensity Score of treated and non-treated before and after matching is presented in an appendix and shows a good quality of our sample matching. Finally, we employ a matched sample to estimate the impacts of board busyness on the bank market value. To do so, we first pool the yearly matched banks having busy boards and banks having non-busy boards. Then, we compute the changes in market value over a 1-year window (presented as " $\Delta$ ", that is, $\Delta \mathrm{y}_{\mathrm{it}+1}=\mathrm{y}_{\mathrm{it}+1}-\mathrm{y}_{\mathrm{it}}$ ), a 2 -year window (presented as " $\Delta$ ", that is, $\Delta \mathrm{y}_{\mathrm{it}+1}=\mathrm{y}_{\mathrm{it}+1}-\mathrm{y}_{\mathrm{it}-1}$ ), and a 3-year window (presented as " $\Delta$ ", that is, $\Delta \mathrm{y}_{\mathrm{it}+1}=\mathrm{y}_{\mathrm{it}+1}-\mathrm{y}_{\mathrm{it}-2}$ ) and estimate the average busyness influences as the differences in the mean changes of the market values between banks having busy boards and 


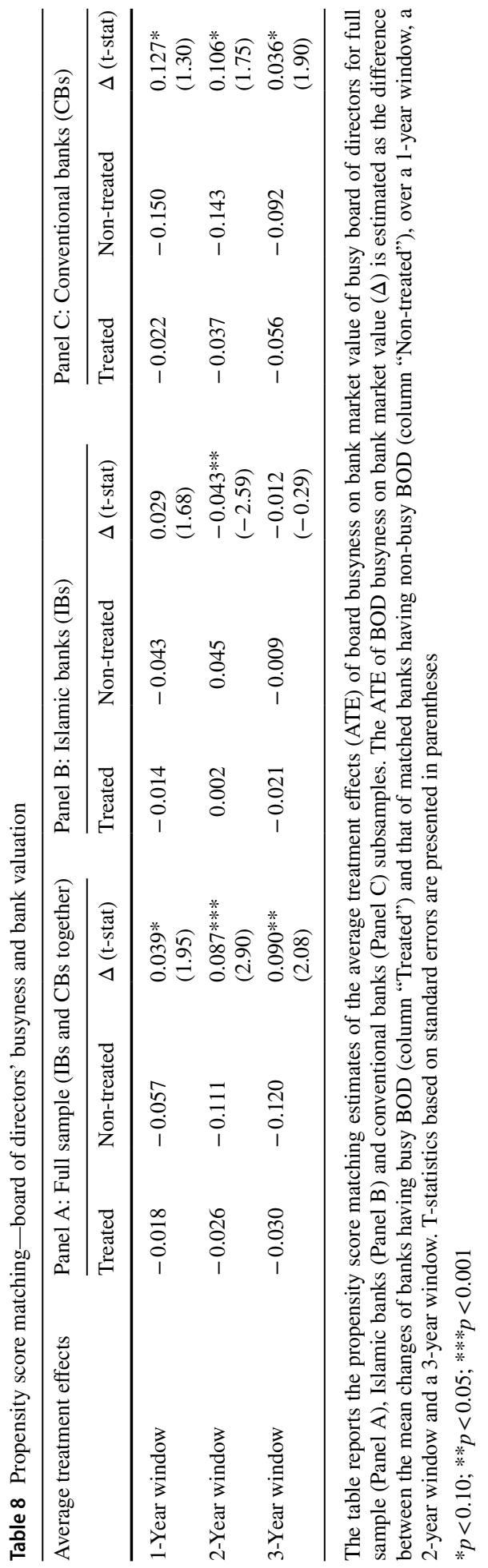


those with non-busy boards. The statistical significance is based on bootstrapped standard errors. If the $\Delta$ is different from zero, the change in bank value over the time window for the banks having busy boards is different from that for the matched banks having non-busy boards (Casu et al. 2013).

Table 8 reports the PSM estimates of the Average Treatment Effects (ATE) of board busyness on bank market value of busy BODs for the full sample (Panel A), IBs (Panel B) and CBs (Panel C) subsamples. The ATE of BOD busyness on bank market value $(\Delta)$ is estimated as the difference between the mean changes of banks having busy BOD (i.e., "Treated" column) and that of matched banks having non-busy BOD (i.e., "Non-treated" column), over a 1-year window, a 2-year window and a 3-year window. Results using PSM are generally consistent with our main findings. Specifically, we find that for full sample, the $\Delta$ is significantly different from zero across all alternative measures for bank value which implies that the change in the market value indicator over the time (1,2 and 3$)$ for the banks having busy BOD is different from that for the matched observations having non-busy BOD. A positive $\Delta$ for bank market value (along with negative coefficients for treated and non-treated sample) suggests a smaller drop in the valuation of investors for banks having a busy BOD. This finding also indicates a positive effect of busy BOD on bank value, which is more pronounced for CBs subsample. As for IBs, a significantly negative $\Delta$ for bank value (along with positive coefficients for treated and non-treated sample) over a 2-year window shows a smaller increase in valuation of banks having a busy BOD. Although we find a more significant drop in value over a 1-year and a 3-year window for banks having busy BOD, none of these estimates is statistically different from zero. Taken together, the PSM approach supports our main findings for the two bank types.

\subsection{Possible non-linear relationship between busy boards and bank value}

Prior literature (e.g., Jiraporn et al. 2009) highlights the possible non-linear relationship between busy boards and bank value. This is derived from the possible varied impacts of board busyness attributes on stock market valuation including busyness and reputation. Jiraporn et al. (2009) argue that a simple linear relation cannot fully explain the association between board busyness and firm performance. For example, at lower degrees of board directorships, the reputation effect may rise higher than a proportional increase in board busyness and hence, it tends to outweigh the cost of the busyness effect. However, at higher degrees, this impact may grow less than proportionately with an increase in board busyness, leading to the dominance of busyness effect.

To check if such non-linear relation exists in our sampled IBs and CBs, we add the square of BOD busyness (i.e., $\% B B O D^{2}$ ) into the $\ln Q$ models (see Table 5). The same (opposite) direction on the coefficient of the square variable (i.e., $\% B B O D^{2}$ ) relative to its original form (i.e., \%BBOD) indicates a linear (non-linear) relationship between busy boards and bank value. We define our simultaneous equations models in Eqs. 7 and 8 as follows:

$$
\begin{aligned}
& \ln Q_{i t}=\beta_{0}+\beta_{1} \% B B O D_{i t}+\beta_{2} \% B B O D_{i t}^{2}+\phi P+\mu \text { Year effects }+\pi \text { Bank effects }+\varepsilon_{i t} \\
& \% B B O D_{i t}=\beta_{0}+\beta_{1} \ln Q_{i t}+\beta_{2} \% B B O D_{i t}^{2}+\phi P+\mu \text { Year effects }+\pi \text { Bank effects }+\varepsilon_{i t}
\end{aligned}
$$


Table 9 Possible non-linear relationship between boards busyness and bank market value_within Islamic and conventional banks

\begin{tabular}{|c|c|c|}
\hline \multirow[t]{2}{*}{ Variables } & Panel A: Islamic banks (IBs) & $\begin{array}{l}\text { Panel B: Con- } \\
\text { ventional banks } \\
(\mathrm{CBs})\end{array}$ \\
\hline & $\begin{array}{l}\ln Q \\
\text { (1) }\end{array}$ & $\begin{array}{l}\ln Q \\
(2)\end{array}$ \\
\hline$\% \mathrm{BBOD}$ & $1.098(0.103)$ & $0.742 * *(0.049)$ \\
\hline$(\% \mathrm{BBOD})^{2}$ & $-0.913^{*}(0.095)$ & $0.963 * * *(0.007)$ \\
\hline$\%$ BSSB & $5.637 * * *(0.000)$ & \\
\hline$(\% \mathrm{BSSB})^{2}$ & $-3.792 * * *(0.000)$ & \\
\hline Bank-level controls & YES & YES \\
\hline Country-level controls & YES & YES \\
\hline Constant & $-4.471 * * *(0.002)$ & $3.402 * *(0.040)$ \\
\hline Year fixed effect & YES & YES \\
\hline Bank fixed effect & YES & YES \\
\hline Observations & 150 & 236 \\
\hline Adjusted $\mathrm{R}^{2}$ & 0.987 & 0.888 \\
\hline $\mathrm{Chi}^{2}$ & $1550 * * *$ & $3908 * * *$ \\
\hline LM statistics ( $p$ value) & 0.000 & 0.000 \\
\hline Sargan test ( $p$ value) & 0.250 & 0.405 \\
\hline$\% B B O D=\% B S S B(F$-test $)$ & 0.000 & \\
\hline
\end{tabular}

The table reports 3LS results for possible non-linear relationships between busy boards and bank market valuation for the Islamic bank subsample (Panel A) and Conventional bank subsample (Panel B). We build simultaneous equations models

$\ln Q_{i t}=\beta_{0}+\beta_{1} \% B B O D_{i t}+\beta_{2}\left(\% B B O D_{i t}\right)^{2}+\phi P+\mu$ Year effects $+\pi$ Bank effects $+\varepsilon_{i t}$
$\% B B O D_{i t}=\beta_{0}+\beta_{1} \ln Q_{i t}+\beta_{2}\left(\% B B O D_{i t}\right)^{2}+\phi P+\mu$ Year effects $+\pi$ Bank effects $+\varepsilon_{i t}$

Where, $\phi \mathrm{P}$ is a vector of control variables in the bank valuation model including bank-level indicators, country-level indicators, and country governance indicators. Models are tested for the period of 6-year from 2010. The diagnostic tests show that LM statistics $p$ value is less than $1 \%$ and Sargan test $p$ value is greater than $10 \%$ across all models, indicating that the chosen IVs for board of directors' busyness are valid and the models are not over-identified

$p$ values in parentheses, ${ }^{*} p<0.10 ; * * p<0.05$; *** $p<0.01$. See Table 2 for other variable definitions

For IBs subsample, in addition to BOD busyness variables (i.e., $\% B B O D ; \% B B O D^{2}$ ), we also add $\% B S S B$ and its square form (i.e., $\% B S S B^{2}$ ) into the above equations to check the non-linear association between SSB busyness and IBs market valuation.

Table 9 reports our main results for non-linear testing. For CBs, we find the same significant and positive sign of $\% B B O D^{2}$, which indicates a simple linear association between busy BOD and firm valuation. This supports the distinctiveness of the roles played and value added from BOD in this banking model. This also supports our main findings for the preferential impacts of BOD busyness on the market valuation of CBs. However, for IBs, the coefficient of $\% B B O D^{2}$ becomes negative and significant while the coefficient on $\% B B O D$ is insignificant, suggesting that IB investors only begin to negatively price the busyness of BOD at the higher degrees of the board outside directorships. Unlike CBs, the reputation effects within IBs appear to reduce proportionally as the outside board directorships increase. Hence, at a higher degree of outside directorships, the busyness effect seems to outweigh the benefits of the reputation effect in this bank type. 
Table 10 Sensitivity tests: using accounting-based measures for bank performance

\begin{tabular}{|c|c|c|c|c|}
\hline \multirow[t]{2}{*}{ Variables } & \multicolumn{2}{|c|}{ Panel A: Islamic banks (IBs) } & \multicolumn{2}{|c|}{ Panel B: Conventional banks (CBs) } \\
\hline & $\begin{array}{l}R O A \\
(1)\end{array}$ & $\begin{array}{l}\text { ROE } \\
(2)\end{array}$ & $\begin{array}{l}R O A \\
(3)\end{array}$ & $\begin{array}{l}R O E \\
(4)\end{array}$ \\
\hline$\% \mathrm{BBOD}$ & $1.741(0.118)$ & $2.020(0.243)$ & $0.792 * * *(0.000)$ & $0.626 * * *(0.000)$ \\
\hline$\%$ BSSB & $-3.012 *(0.069)$ & $-3.274 *(0.071)$ & & \\
\hline LogBSIZE & $-0.804 * *(0.014)$ & $-1.079 * * *(0.008)$ & $0.071(0.121)$ & $0.067(0.101)$ \\
\hline INDEP & $-0.251(0.531)$ & $-0.426(0.341)$ & $-0.239 * * *(0.000)$ & $-0.207 * * *(0.000)$ \\
\hline LogTA & $-0.396(0.102)$ & $-0.020(0.945)$ & $-0.057(0.120)$ & $-0.040(0.223)$ \\
\hline CAPEX/ASSETS & $0.002(0.806)$ & $0.008(0.458)$ & $-0.001(0.914)$ & $0.002(0.773)$ \\
\hline CASH/ASSETS & $0.782(0.489)$ & $0.230(0.870)$ & $-0.398 * *(0.049)$ & $-0.359 * *(0.043)$ \\
\hline LEV & $-0.078 * * *(0.008)$ & $-0.056 *(0.087)$ & $-0.001(0.861)$ & $0.007 *(0.072)$ \\
\hline BIG4 & $0.687(0.123)$ & $0.287(0.548)$ & $-0.103 * *(0.039)$ & $-0.081 *(0.067)$ \\
\hline HHI & $0.469(0.276)$ & $0.652(0.175)$ & $-0.063(0.600)$ & $-0.017(0.868)$ \\
\hline GDPCAPITA & $-0.001(0.959)$ & $-0.001(0.925)$ & $-0.007 * * *(0.000)$ & $-0.005 * * *(0.000)$ \\
\hline COUNTRY_GOV & $-0.441(0.382)$ & $-0.498(0.357)$ & $0.223 * * *(0.003)$ & $0.133 * *(0.038)$ \\
\hline Constant & $10.545 * * *(0.005)$ & $5.573(0.211)$ & $0.537(0.362)$ & $0.264(0.614)$ \\
\hline Year fixed effect & YES & YES & YES & YES \\
\hline Bank fixed effect & YES & YES & YES & YES \\
\hline Observations & 150 & 150 & 236 & 236 \\
\hline Adjusted $\mathrm{R}^{2}$ & 0.543 & 0.400 & 0.504 & 0.469 \\
\hline $\mathrm{Chi}^{2}$ & $100 * * *$ & $68 * * *$ & $379 * * *$ & $238 * * *$ \\
\hline LM statistics ( $p$ value) & 0.000 & 0.000 & 0.000 & 0.000 \\
\hline Sargan test ( $p$ value) & 0.260 & 0.236 & 0.105 & 0.143 \\
\hline $\begin{array}{l}\% B B O D=\% B S S B \\
(F \text {-test })\end{array}$ & 0.000 & 0.000 & & \\
\hline
\end{tabular}

The table presents 3SLS results when using an accounting-based measures for bank performance: (1) return on assets (ROA) and (2) return on equity (ROE) for the Islamic bank subsample (Panel A) and conventional bank subsample (Panel B)

$p$ values in parentheses, ${ }^{*} p<0.10 ;{ }^{*} p<0.05 ;{ }^{* * *} p<0.01$. See Table 2 for other variable definitions

Furthermore, within IBs, we find the sign of the coefficient on $\% B S S B^{2}$ become significantly negative compared to its original form $\% B S S B$. This suggests an inverted non-linear linkage between SSB busyness and valuations of IB investors. Specifically, at a lower degree of outside directorships, busy SSB is associated with higher investors' valuations. However, as the degree of outside directorships increases, the SSB busyness significantly reduces bank market value, which supports our main findings and highlights the detrimental impact of recruiting busy SSB on IBs' valuation due to substantial lax screening.

\subsection{Using accounting-based measures for bank performance}

To address potential measurement errors related to the use of Tobin's q, we use alternative measures for bank accounting-based performance represented by the return on assets 
Table 11 Sensitivity tests: using alternative measure for boards busyness

\begin{tabular}{|c|c|c|}
\hline \multirow[t]{2}{*}{ Variables } & Panel A: Islamic banks (IBs) & $\begin{array}{l}\text { Panel B: Conven- } \\
\text { tional banks (CBs) }\end{array}$ \\
\hline & $\begin{array}{l}\ln Q \\
(1)\end{array}$ & $\begin{array}{l}\operatorname{Ln} Q \\
(2)\end{array}$ \\
\hline ABOD & $-0.046(0.349)$ & $0.080 * * *(0.000)$ \\
\hline ASSB & $-1.256^{* *}(0.049)$ & \\
\hline LogBSIZE & $-0.603 * *(0.014)$ & $0.100(0.129)$ \\
\hline INDEP & $-0.715 * *(0.028)$ & $-0.254 * * *(0.003)$ \\
\hline $\log \mathrm{TA}$ & $-0.426(0.125)$ & $-0.168 * * *(0.004)$ \\
\hline CAPEX/ASSETS & $-0.032(0.120)$ & $-0.001(0.737)$ \\
\hline CASH/ASSETS & $3.317(0.101)$ & $-0.107(0.750)$ \\
\hline LEV & $-0.062(0.137)$ & $0.003(0.643)$ \\
\hline BIG4 & $-2.435 * *(0.049)$ & $-0.076(0.286)$ \\
\hline HHI & $-1.326^{*}(0.065)$ & $0.428 * *(0.024)$ \\
\hline GDPCAPITA & $0.002(0.797)$ & $-0.006 * *(0.029)$ \\
\hline COUNTRY_GOV & $0.362(0.401)$ & $0.196 *(0.069)$ \\
\hline Constant & $28.750 * *(0.049)$ & $2.221 * *(0.024)$ \\
\hline Year fixed effect & YES & YES \\
\hline Bank fixed effect & YES & YES \\
\hline Observations & 150 & 236 \\
\hline Adjusted $\mathrm{R}^{2}$ & 0.823 & 0.978 \\
\hline $\mathrm{Chi}^{2}$ & $2625 * * *$ & $1082 * * *$ \\
\hline LM statistics ( $p$ value) & 0.000 & 0.000 \\
\hline Sargan test ( $p$ value) & 0.114 & 0.157 \\
\hline$\% B B O D=\% B S S B(F$-test $)$ & 0.000 & \\
\hline
\end{tabular}

The table presents 3SLS results when using an alternative measure of board busyness: (1) average outside directorships per outside director $(A B O D)$ and (2) average outside directorships per Shari'ah advisors $(A S S B)$ for the Islamic bank subsample (Panel A) and Conventional bank subsample (Panel B)

$p$ values in parentheses, ${ }^{*} p<0.10 ; * * p<0.05$; ${ }^{* * *} p<0.01$. See Table 2 for other variable definitions

$(R O A)$ and return on equity (ROE) (Fich and Shivdasani 2006; Cashman et al. 2012). ${ }^{14}$ Specifically, we examine our two study hypotheses across both bank types using these alternative measures as our dependent variables.

Results are reported in Table 10 for both bank types and, generally, remain unchanged. For IBs, we find no significant evidence on the association between firm performance and busy BOD, but a busy SSB is associated with significantly low firm performance. In contrast, CBs report a positive association between the busy board and each of the indicators $R O A$ and ROE. These results suggest that our main findings are not driven by potential measurement errors or model misspecifications when using $\ln Q$.

\footnotetext{
14 Unreported descriptive statistics show that IBs have a significantly lower ROA (ROE) of 0.476 (7.707) in comparison with their conventional counterparts $(1.585 ; 12.827)$.
} 
Table 12 Robustness checks: using first-differenced regression models

\begin{tabular}{|c|c|c|}
\hline \multirow[t]{2}{*}{ Variables } & Panel A: Islamic banks (IBs) & $\begin{array}{l}\text { Panel B: Con- } \\
\text { ventional banks } \\
(\mathrm{CBs})\end{array}$ \\
\hline & $\begin{array}{l}\ln Q \\
\text { (1) }\end{array}$ & $\begin{array}{l}\ln Q \\
(2)\end{array}$ \\
\hline D.\%BBOD & $0.121(0.202)$ & $0.382 * * *(0.000)$ \\
\hline D. $\%$ BSSB & $-0.741 * * *(0.007)$ & \\
\hline D.LogBSIZE & $0.045(0.386)$ & $0.103(0.176)$ \\
\hline D.INDEP & $-0.026(0.752)$ & $-0.220 *(0.085)$ \\
\hline D.LogTA & $0.036(0.568)$ & $0.228 * *(0.014)$ \\
\hline D.CAPEX/ASSETS & $0.003 * *(0.046)$ & $-0.001(0.802)$ \\
\hline D.CASH/ASSETS & $0.057(0.786)$ & $-0.588 *(0.098)$ \\
\hline D.LEV & $0.018 * * *(0.009)$ & $-0.012(0.165)$ \\
\hline BIG4 & $-0.047 * *(0.027)$ & $-0.081(0.377)$ \\
\hline D.HHI & $0.018(0.808)$ & $0.397 *(0.088)$ \\
\hline D.GDPCAPITA & $-0.001(0.434)$ & $-0.001 * *(0.045)$ \\
\hline D.COUNTRY_GOV & $0.023(0.365)$ & $0.137 * * *(0.001)$ \\
\hline Constant & $-0.064 * *(0.028)$ & $0.016(0.618)$ \\
\hline Year fixed effect & YES & YES \\
\hline Observations & 123 & 193 \\
\hline Adjusted $\mathrm{R}^{2}$ & 0.008 & 0.267 \\
\hline $\mathrm{Chi}^{2}$ & $42 * * *$ & $55^{* * *}$ \\
\hline LM statistics ( $p$ value) & 0.000 & 0.000 \\
\hline Sargan test ( $p$ value) & 0.243 & 0.063 \\
\hline$\% B B O D=\% B S S B(F-t e s t)$ & 0.000 & \\
\hline
\end{tabular}

The table presents first-differenced regression (3SLS) results for the Islamic bank subsample (Panel A) and Conventional bank subsample (Panel B) identifying the effect of busy board of directors or busy SSB on a bank's firm value

$p$ values in parentheses, ${ }^{*} p<0.10 ; * * p<0.05 ; * * * p<0.01$. First-differenced models are used to control for time-invariant unobserved effects. See Table 2 for other variable definitions

\subsection{Using alternative measures for busy boards}

We change our measure of busy boards and re-estimated the main models by using an alternative measure of board busyness (see Fich and Shivdasani 2006; Cashman et al. 2012). These measures are the average outside directorships per outside director (ABOD) and the average outside directorships per Shari'ah advisors (ASSB). The results are reported in Table 11 and show consistent observations for busy BOD across the two bank types and also for busy SSB within IBs.

\subsection{Using first-differenced regression models}

In this section, we capture unobserved time-invariant effects by employing first-differenced regressions for all variables (except for dummy variable BIG4) in 3SLS models. Results for IBs and CBs subsample are presented in Table 12 (Panel A and B, respectively). Our 
results remain unchanged for both bank types. That is, a busy BOD in CBs is highly-priced than that in IBs, and SSB busyness is detriment the stock market valuations of IBs.

We additionally test the robustness of our results using a two-step system Generalized Method of Moments (GMM) estimator (Arellano and Bover 1995; Blundell and Bond 1998). The GMM also controls for the unobserved effects by transforming the variables into first-differences to eliminate unobserved heterogeneity and omitted variable bias. It allows us to treat all bank characteristics variables as endogenous and orthogonally employs the lag values of endogenous variables as IVs (Hermalin and Weisbach 2003; Mollah and Zaman 2015; Mollah et al. 2017). Macroeconomics control variables are treated as strictly exogenous. Unreported results are found to be consistent with the main findings identified through 3SLS. Overall findings in this section indicate that our main results are not affected by unobserved heterogeneity, simultaneity and dynamic endogeneity.

\section{Conclusions}

Motivated by the long controversy regarding the effect of board busyness on firm value, we investigate whether board busyness affects stock market valuations. To the best of our knowledge, it is the first study to examine this association in banking and specifically the first study to identify possible differential valuations of board busyness across alternative banking systems (i.e., Islamic versus conventional banks). Our results indicate that a busy board of directors generally promotes high market valuations in support of additional preferential benefits that a busy board can generate for their banks. However, investors across the two bank types showed distinct perceptions of appointing a busy board of directors. In conventional banks, investors assign a high valuation for busy board while Islamic banks' investors do not significantly price a busy board. Our results also show that investors in Islamic banks consistently perceive busy Shari'ah boards as damaging the bank value. Additional analyses indicate that underlying channels, such as the agency conflicts and board compensation, can explain the different effects between the two bank types of board busyness on market valuations.

Overall findings suggest that investors engaging with Islamic banking tend to be more sensitive to SSB busyness while they penalise their banks for not allocating any significant pricing for the board of directors' busyness. These results imply that despite the importance of having a double-layer governance mechanism in an Islamic banking system, enhancing the credibility and trust for this banking business model might not hold in the presence of lax monitoring. This could promote withdrawal and systematic risks for this banking sector. Results showing the positive influence of board busyness on conventional banks' valuations can partially alleviate concerns related to ineffective monitoring. These findings reinforce the evidence by Conyon and Read (2006) indicating that limiting the number of directorships of the board of directors is not necessarily an ideal regulatory response to board busyness. Furthermore, Islamic banks can learn from conventional banks on how to effectively exploit the possible reputation benefits associated with appointing busy outside directors and how to successfully signal such information to stock markets to increase the equity value for their banks.

Findings in this study contribute to the on-going debate related to the different layers of governance mechanisms and the importance of considering institutional environments as well as distinct business models employed by alternative banking systems. Results in this study can inform both investors' investment choices and regulators about the implications that board 
busyness could have, distinctively, on the two bank types. Moreover, for countries operating on dual-banking systems, standard setters should provide detailed guidance to govern board multiple-directorships and to consider stock market responsiveness to busyness information within different bank settings. Future research in this arena may extend the busyness issue and assess the economic consequences of appointing a busy board with sufficient and relevant qualifications (e.g., accounting and financial expertise and continuing education).

Acknowledgements We would like to thank the editor, associate editor and two anonymous reviewers for their valuable feedback and directions. This research did not receive any specific grant from funding agencies in the public, commercial, or non-for-profit sectors.

Open Access This article is distributed under the terms of the Creative Commons Attribution 4.0 International License (http://creativecommons.org/licenses/by/4.0/), which permits unrestricted use, distribution, and reproduction in any medium, provided you give appropriate credit to the original author(s) and the source, provide a link to the Creative Commons license, and indicate if changes were made.

\section{Appendix: Distribution of the propensity Score of treated and non-treated before and after matching}
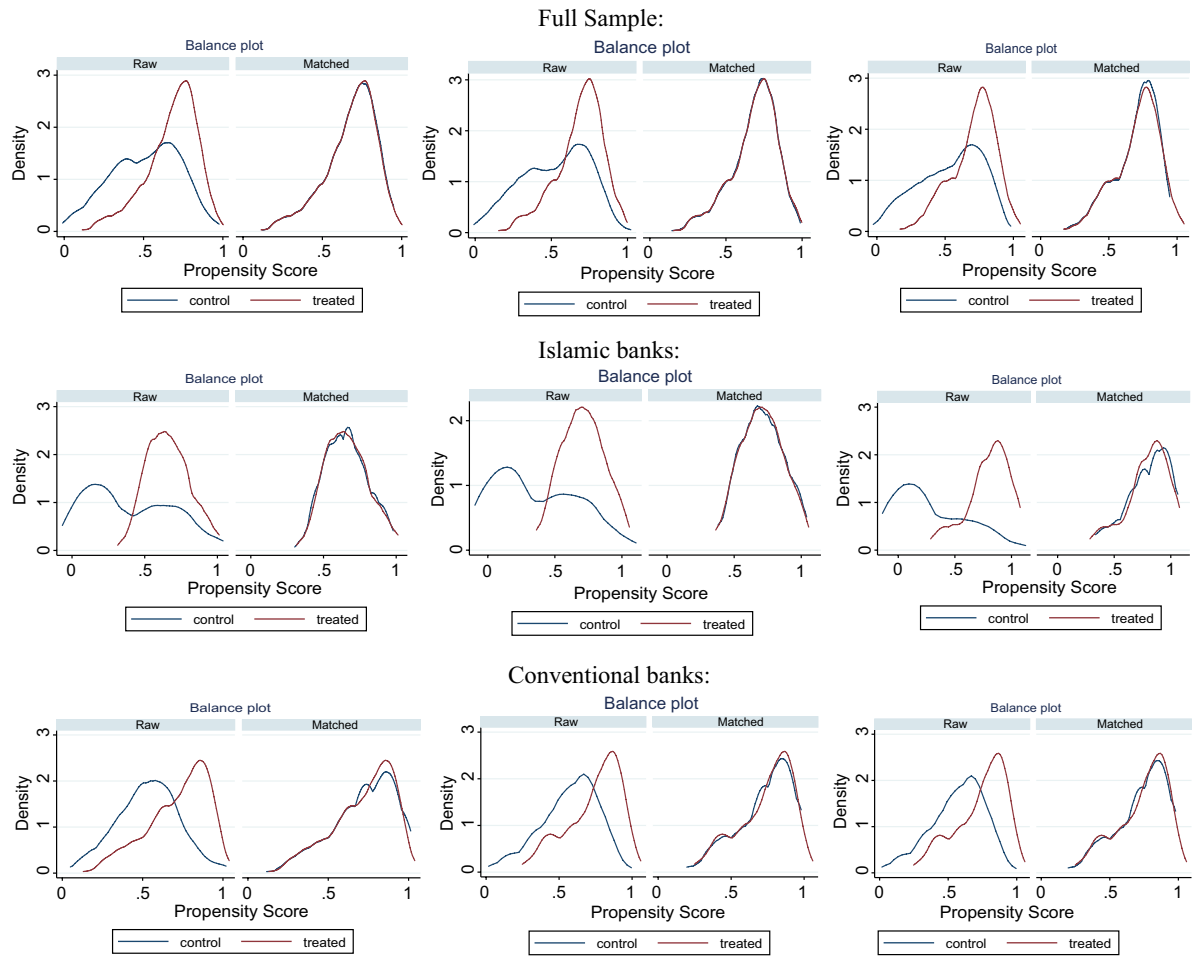


\section{References}

Abbott LJ, Parker S, Peters GF (2004) Audit committee characteristics and restatements. Audit J Pract Theory 23:69-87

Abdel Karim RA (2001) International accounting harmonization, banking regulation, and Islamic banks. Int J Account 36:169-193

Abdelsalam O, Dimitropoulos P, Elnahass M, Leventis S (2016) Earnings management behaviours under different monitoring mechanisms: the case of Islamic and conventional banks. J Econ Behav Organ 132:155-173

Abedifar P, Molyneux P, Tarazi A (2013) Risk in Islamic banking. Rev Finance 17:2035-2096

Adams R, Mehran H (2003) Is corporate governance different for bank holding companies? Econ Policy Rev 9:123-142

Aggarwal R, Erel I, Stulz R, Williamson R (2009) Differences in governance practice between U.S. and foreign firms: measurement, causes, and consequences. Rev Financ Stud 22:3131-3169

Alandejani M, Kutan AM, Samargandi N (2017) Do Islamic banks fail more than conventional banks? J Int Financ Mark Inst Money 50:135-155

Allen F, Faulhaber GR (1989) Signalling by underpricing in the IPO market. J Financ Econ 23:303-323

Alnasser SAS, Muhammed J (2012) Introduction to corporate governance from Islamic perspective. Humanomics 28:220-231

Alqahtani F, Mayes DG, Brown K (2017) Islamic bank efficiency compared to conventional banks during the global crisis in the GCC region. J Int Financ Mark Inst Money 51:58-74

Alsaadi A, Ebrahim MS, Jaafar A (2017) Corporate social responsibility, Shariah-compliance, and earnings quality. J Financ Serv Res 51:169-194

Ammann M, Oesch D, Schmid MM (2011) Corporate governance and firm value: international evidence. J Empir Finance 18:36-55

Ararat M, Aksu MH, Tansel CA (2010) The impact of board diversity on boards' monitoring intensity and firm performance: evidence from the Istanbul Stock Exchange. SSRN electronic paper

Archer S, Karim RAA (2007) Specific corporate governance issues in islamic banks. Islam Finance Regul Chall 394:310-341

Arellano M, Bover O (1995) Another look at the instrumental variable estimation of error-component models. J Econom 68:29-51

Baek HY, Johnson DR, Kim JW (2009) Managerial ownership, corporate governance, and voluntary disclosure. J Bus Econ Stud 15:44-61

Ball R, Robin A, Wu JS (2003) Incentives versus standards: properties of accounting income in four East Asian countries. J Account Econ 36:235-270

Ballas AA, Chalevas C, Tzovas C (2012) Market reaction to valuation adjustments for financial instruments: evidence from Greece. J Int Account Audit Tax 21:52-61

Barth JR, Caprio G, Levine R (2001) The regulation and supervision of bank around the world: a new database. In: Litan RE, Herring R (eds) Integrating emerging market countries into the global financial system. Brookings Institution Press, Washington

Beck T, Demirgüç-Kunt A, Merrouche O (2013) Islamic vs. conventional banking: business model, efficiency and stability. J Bank Finance 37:433-447

Beekun RI, Badawi JA (2005) Balancing ethical responsibility among multiple organizational stakeholders: the Islamic perspective. J Bus Ethics 60:131-145

Belkhir M (2009) Board of directors' size and performance in the banking industry. Int J Manag Finance 5:201-221

Bergh DD, Connelly BL, Ketchen DJ, Shannon LM (2014) Signalling theory and equilibrium in strategic management research: an assessment and a research agenda. J Manage Stud 51:1334-1360

Bhagat S, Black B (2001) The non-correlation between board independence and long-term firm performance. J Corp Law 27:231-273

Black B, Kim W (2012) The effect of board structure on firm value: a multiple identification strategies approach using Korean data. J Financ Econ 104:203-226

Black BS, Jang H, Kim W (2006) Does corporate governance predict firms' market values? Evidence from Korea". J Law Econ Organ 22:366-413

Black BS, Carvalho AG, Gorga E (2012) What matters and for which firms for corporate governance in emerging markets? Evidence from Brazil (and other BRIK countries). J Corp Finance 18:934-952

Black BS, De Carvalho AG, Sampaio JO (2014) The evolution of corporate governance in Brazil. Emerg Mark Rev 20:176-195

Black BS, Kim W, Jang H, Park KS (2015) How corporate governance affect firm value? Evidence on a self-dealing channel from a natural experiment in Korea. J Bank Finance 51:131-150 
Blundell R, Bond S (1998) Initial conditions and moment restrictions in dynamic panel data models. J Econ $87: 115-143$

Boateng A, Bi X, Brahma S (2017) The impact of firm ownership, board monitoring on operating performance of Chinese mergers and acquisitions. Rev Quant Financ Acc 49:925-948

Bose S (2014) Capital market impact of the disclosure, assurance and management of greenhouse gas (GHG) emissions: an international study. Unpublished doctoral dissertation, UNSW Australia, Sydney, Australia

Brennan NM, Kirwan CE, Redmond J (2016) Accountability processes in boardrooms: a conceptual model of manager-non-executive director information asymmetry. Account Audit Account $\mathbf{J}$ 29:135-164

Brick IE, Palmon O, Wald JK (2006) CEO compensation, director compensation, and firm performance: evidence of cronyism? J Corp Finance 12:403-423

Brown LD, Caylor ML (2006) Corporate governance and firm valuation. J Acc Public Policy 25:409-434

Busch T, Hoffmann VH (2011) How hot is your bottom line? Linking carbon and financial performance. Bus Soc 50:233-265

Caliendo M, Kopeinig S (2008) Some practical guidance for the implementation of propensity score matching. J Econ Surv 22(1):31-72

Caprio G, Laeven L, Levine R (2007) Governance and bank valuation. J Financ Intermed 16:584-617

Cashman GD, Gillan SL, Jun C (2012) Going overboard? On busy directors and firm value. J Bank Finance 36:3248-3259

Casu B, Clare A, Sarkisyan A, Thomas S (2013) Securitization and bank performance. J Money Credit Bank 45(8):1617-1658

Chakravarty S, Rutherford LG (2017) Do busy directors influence the cost of debt? An examination through the lens of takeover vulnerability. J Corp Finance 43:429-443

Chan WS, Frankel R, Kothari SP (2004) Testing behavioral finance theories using trends and consistency in financial performance. $\mathrm{J}$ Account Econ 38:3-50

Chang CC, Ho KY, Hsiao YJ (2018) Derivatives usage for banking industry: evidence from the European markets. Rev Quant Finance Acc 6:1-21

Chen IJ (2016) Corporate governance and the efficiency of internal capital markets. Rev Pac Basin Financ Mark Polic 19:1650013

Chen YK, Shen CH, Kao L, Yeh CY (2018) Bank liquidity risk and performance. Rev Pac Basin Financ Mark Polic 21:1-40

Cheng CA, Collins D, Huang HH (2006) Shareholder rights, financial disclosure and the cost of equity capital. Rev Quant Financ Acc 27:175-204

Cheng S, Evans JH, Nagarajan NJ (2008) Board size and firm performance: the moderating effects of the market for corporate control. Rev Quant Financ Acc 31:121-145

Choi TH, Jung J (2008) Ethical commitment, financial performance, and valuation: an empirical investigation of Korean companies. J Bus Ethics 81:447-463

Choi JJ, Park SW, Yoo SS (2007) The value of outside directors: evidence from corporate governance reform in Korea. J Financ Quant Anal 42:941-962

Chou TK, Feng HL (2018) Multiple directorships and the value of cash holdings. Rev Quant Finance Account. https://doi.org/10.1007/s11156-018-0762-1

Čihák M, Hesse H (2010) Islamic banks and financial stability: an empirical analysis. J Financ Serv Res 38:95-113

CII (2003) Council for institutional investors' corporate governance policies

Clifford CP, Ellis JA, Gerken WC (2017) Hedge fund boards and the market for independent directors. Schnatter Institute working paper, John H. Schnatter Institute for the Study of Free Enterprise, University of Kentucky, Lexington, KY

Coles J, Daniel N, Naveen L (2008) Boards: does one size fit all? J Financ Econ 87:329-356

Conyon MJ, Read LE (2006) A model of the supply of executives for outside directorships. J Corp Finance 12:645-659

Core JE, Holthausen RW, Larcker DF (1999) Corporate governance, chief executive officer compensation, and firm performance. J Financ Econ 51:371-406

Craswell A, Stokes DJ, Laughton J (2002) Auditor independence and fee dependence. J Account Econ 33:253-275

Dah MA, Frye MB (2017) Is board compensation excessive? J Corp Finance 45:566-585

De Haan J, Vlahu R (2013) Corporate governance of banks: a survey. De Nederlandsche bank working paper no. 386

DeBoskey DG, Luo Y, Zhou L (2019) CEO power, board oversight, and earnings announcement tone. Rev Quant Financ Acc 52:657-680 
Dittmar A, Mahrt-Smith J (2007) Corporate governance and the value of cash holdings. J Financ Econ 83:599-634

Eisenberg T, Sundgren S, Wells M (1998) Larger board size and decreasing firm value in small firms. J Financ Econ 48:35-54

Elnahass M, Izzeldin M, Abdelsalam O (2014) Loan loss provisions, bank valuations and discretion: a comparative study between conventional and Islamic banks. J Econ Behav Organ 103:S106-S173

Elnahass M, Izzeldin M, Steele G (2018) Capital and earnings management: evidence from alternative banking business models. Int J Account 53:20-32

Elyasiani E, Jia JJ (2008) Institutional ownership stability and BHC performance. J Bank Finance 32:1767-1781

Elyasiani E, Zhang L (2015) Bank holding company performance, risk, and "busy" board of directors. J Bank Finance 60:239-251

Epstein MJ, McEwen RA, Spindle RM (1994) Shareholder preferences concerning corporate ethical performance. J Bus Ethics 13:447-453

Falato A, Kadyrzhanova D, Lel U (2014) Distracted directors: does board busyness hurt shareholder value? J Financ Econ 113:404-426

Faleye O, Krishnan K (2017) Risky lending: does bank corporate governance matter? J Bank Finance $83: 57-69$

Faleye O, Hoitash R, Hoitash U (2011) The costs of intense board monitoring. J Financ Econ 101:160-181

Faleye O, Hoitash R, Hoitash U (2018) Industry expertise on corporate boards. Rev Quant Financ Acc 50:441-479

Farag H, Mallin C, Ow-Yong K (2018) Corporate governance in Islamic banks: new insights for dual board structure and agency relationships. J Int Financ Mark Inst Money 54:59-77

Ferris SP, Jagannathan M, Pritchard AC (2003) Too busy to mind the business? Monitoring by directors with multiple board appointments. J Finance 58:1087-1111

Fich EM, Shivdasani A (2006) Are busy boards effective monitors? J Finance 61:689-724

Field L, Lowry M, Mkrtchyan A (2013) Are busy boards detrimental? J Financ Econ 109:63-82

Godlewski CJ, Turk-Ariss R, Weill L (2016) Do the type of sukuk and choice of shari'a scholar matter? J Econ Behav Organ 132:63-76

Goldberg PK, Pavcnik N (2007) Distributional effects of globalization in developing countries. J Econ Lit 45:39-82

Gompers PA, Ishii J, Metrick A (2003) Corporate governance and equity prices. Quart J Econ 118:107-155

Goncalves R, Lopes P, Craig R (2017) Value relevance of biological assets under IFRS. J Int Account Audit Tax 29:118-126

Guest PM (2009) The impact of board size on firm performance: evidence from the UK. Eur J Finance 15:385-404

Gyapong E, Monem RM, Hu F (2016) Do women and ethnic minority directors influence firm value? Evidence from post-apartheid South Africa. J Bus Finance Account 43:370-413

Harkin SM, Mare DS, Crook JN (2019) Average pay in banks: do agency problems and bank performance matter? Rev Quant Financ Acc 53:101-122

Harris IC, Shimizu K (2004) Too Busy to Serve? An examination of influence of over-boarded directors. J Manage Stud 41:775-798

Hart O (1995) Corporate governance: some theory and implications. Econ J 105:678-689

Hausman JA (1978) Specification tests in econometrics. Econometrica 46(6):1251-1271

Henry D (2008) Corporate governance structure and the valuation of Australian firms: is there value in ticking the boxes? J Bus Finance Account 35:912-942

Hermalin B, Weisbach M (2003) Board of directors as an endogenously determined institution: a survey of the economic literature. Econ Policy Rev 9:7-26

Higgins MC, Gulati R (2006) Stacking the deck: the effects of top management backgrounds on investor decisions. Strateg Manag J 27:1-25

Hillman AJ, Dalziel T (2003) Boards of directors and firm performance: integrating agency and resource dependence perspectives. Acad Manag Rev 28:383-396

Hsu HH, Wu CYH (2014) Board composition, grey directors and corporate failure in the UK. Br Account Rev 46(3):215-227

Islamic Financial Services Board (2005) Capital adequacy standard for institutions (other than insurance institutions) offering only Islamic financial services. http://www.ifsb.org. Accessed 15 Mar 2017

Islamic Financial Services Board (2017) Islamic financial services industry stability report 2017. http:// www.ifsb.org. Accessed 03 Aug 2018

Jackling B, Johl S (2009) Board structure and firm performance: evidence from India's top companies. Corp Gov Int Rev 17:492-509 
Jamali D, Safieddine AM, Rabbath M (2008) Corporate governance and corporate social responsibility synergies and interrelationships. Corp Gov Int Rev 16:443-459

Jensen MC (1986) Agency costs of free cash flow, corporate finance and takeovers. Am Econ Rev 76:323-339

Jensen M, Meckling W (1976) Theory of the firm: managerial behavior, agency costs and ownership structure. J Financ Econ 3:305-360

Jensen MC, Murphy KJ (1990) Performance pay and top-management incentives. J Polit Econ 98(2):225-264

Jiraporn P, Kim YS, Davidson WN (2008) Multiple directorships and corporate diversification. J Empir Finance 15:418-435

Jiraporn P, Singh M, Lee CI (2009) Ineffective corporate governance: director busyness and board committee memberships. J Bank Finance 33(5):819-828

Johnes J, Izzedin M, Pappas V (2014) A comparison of performance of Islamic and conventional banks 2004-2009. J Econ Behav Organ 103:S93-S107

Jouida S (2019) Bank capital structure, capital requirements and SRISK across bank ownership types and financial crisis: panel VAR approach. Rev Quant Financ Acc 53:295-325

Kaufmann D, Kraay A, Mastruzzi M (2005) Governance matters IV: governance indicators for 1996-2004. Policy research working paper, 3630, World Bank, Washington, mimeo

Khan F (2010) How 'Islamic' is Islamic banking? J Econ Behav Organ 76:805-820

Kini O, Kracaw W, Mian S (1995) Corporate takeovers, firm performance, and board composition. J Corp Finance 1:383-412

Kraatz MS, Zajac EJ (2001) How firm resources affect strategic change and performance in turbulent environments: theory and evidence. Organ Sci 12:632-657

La Porta R, Lopez-de-Silanes F, Shleifer A (2002) Government ownership of commercial banks. J Finance 57:265-301

Lahsasna A (2010) Introduction to fatwa, Shariah supervision \& governance in Islamic finance. CERT Publications Sdn. Bhd, Kuala Lumpur

Lassoued N, Attia MBR, Sassi H (2017) Earnings management in Islamic and conventional banks: does ownership structure matter? Evidence from the MENA region. J Int Account Audit Tax 30:85-105

Lawrence A, Minutti-Meza M, Zhang P (2010) Can Big 4 versus Non-Big4 difference in audit quality proxies be attributed to client characteristics? Account Rev 86:259-286

Li ZF (2014) Mutual monitoring and corporate governance. J Bank Finance 45:255-269

Lin ZJ, Liu M (2009) The impact of corporate governance on auditor choice: evidence from China. J Int Account Audit Tax 18:44-59

Linn SC, Park D (2005) Outside director compensation policy and the investment opportunity set. J Corp Finance 11:680-715

Liu S (2015) Corporate governance and forward-looking disclosure: evidence from China. J Int Account Audit Tax 25:16-30

Lu J, Boateng A (2017) Board composition, monitoring and credit risk: evidence from the UK banking industry. Rev Quant Financ Acc 51:1-22

Luo Q, Hachiya T (2005) Corporate governance, cash holdings, and firm value: evidence from Japan. Rev Pac Basin Financ Mark Polic 8:613-636

Machuga S, Teitel K (2009) Board of director characteristics and earnings quality surrounding implementation of a corporate governance code in Mexico. J Int Account Audit Tax 18:1-13

Malkawi BH (2013) Shari'ah board in the governance structure of Islamic Financial Institutions. Am J Comp Law 61:539-578

Mallette P, Fowler KL (1992) Effects of board composition and stock ownership on the adoption of "poison pills". Acad Manag J 35:1010-1035

Masulis RW, Mobbs S (2014) Independent director incentives: where do talented directors spend their limited time and energy? J Financ Econ 111:406-429

Meng Y, Clements MP, Padgett C (2018) Independent directors, information costs and foreign ownership in Chinese companies. J Int Financ Mark Inst Money 53:139-157

Mitra S, Jaggi B, Al-Hayale T (2019) Managerial overconfidence, ability, firm-governance and audit fees. Rev Quant Financ Acc 52:841-870

Mollah S, Zaman M (2015) Shari'ah supervision, corporate governance and performance: conventional vs. Islamic banks. J Bank Finance 58:418-435

Mollah S, Hassan MK, Al Farooque O, Mobarek A (2017) The governance, risk-taking, and performance of Islamic banks. J Financ Serv Res 51:195-219

Muravyev A, Talavera O, Weir C (2016) Performance effects of appointing other firms' executive directors to corporate boards: an analysis of UK firms. Rev Quant Financ Acc 46:25-45 
National Association of Corporate Directors (1996) NACD blue ribbon commission report on director professionalism

Nguyen T, Locke S, Reddy K (2015) Does boardroom gender diversity matter? Evidence from a transitional economy. Int Rev Econ Finance 37:184-202

O’Sullivan D (1996) A sector with everything still to play for. Middle East Econ Dig 40:7-9

Olson D, Zoubi TA (2008) Using accounting ratios to distinguish between Islamic and conventional banks in the GCC region. Int J Account 43:45-65

Pae J, Choi TH (2011) Corporate governance, commitment to business ethics, and firm valuation: evidence from the Korean stock market. J Bus Ethics 100:323-348

Peng L, Xiong W (2006) Investor attention, overconfidence and category learning. J Financ Econ 80:563-602

Perry T, Peyer U (2005) Board seat accumulation by executives: a shareholder's perspective. J Finance 60:2083-2123

Pomeranz F (1997) The accounting and auditing organization for Islamic Financial Institutions: an important regulatory debut. J Int Account Audit Tax 6:123-130

Quttainah MA, Song L, Wu Q (2013) Do Islamic banks employ less earnings management? J Int Financ Manag Account 24:203-233

Renneboog L, Trojanowski G (2011) Patterns in payout policy and payout channel choice. J Bank Finance 35:1477-1490

Reuters (2012) Insight: "rock star" scholars a risk for Islamic finance. Oxford Business Group: The Report: Bahrain 2008, London, United Kingdom

Saeed M, Izzeldin M (2016) Examining the relationship between default risk and efficiency in Islamic and conventional banks. J Econ Behav Organ 132:127-154

Safieddine A (2009) Islamic financial institutions and corporate governance: new insights for agency theory. Corp Gov Int Rev 17:142-158

Sami H, Wang J, Zhou H (2011) Corporate governance and operating performance of Chinese listed firms. J Int Account Audit Tax 20:106-114

Thomas DE, Eden L (2004) What is the shape of the multinationality-performance relationship? Multinatl Bus Rev 12:89-110

Wernerfelt B, Montgomery CA (1988) Tobin's q and the importance of focus in firm performance. Am Econ Rev 78:246-250

Wilson R (2009) Shari'ah governance for Islamic financial institutions. ISRA Int J Islam Finance 1:59-75

Wooldridge JM (2002) Economic analysis of cross-section and panel data. MIT Press, London

World Bank (2015) World Bank country and lending groups. https://datahelpdesk.worldbank.org. Accessed $15 \mathrm{Jul} 2016$

World Bank (2016) Labor market polarization in developing countries: challenges ahead. http://blogs.world bank.org. Accessed 01 Aug 2017

Wu DM (1973) Alternative tests of independence between stochastic regressors and disturbances. Econom J Econom Soc 41:733-750

Yeh YH, Shu PG, Kao MS (2015) Corporate governance and private equity placements. Rev Pac Basin Financ Mark Polic 18:1550013

Yermack D (1996) Higher market valuation of companies with a small board of directors. J Financ Econ 40:185-211

Zhang EJ (2016) Preoccupied independent directors. Working paper, UNSW Business School

Zoubi TA, Salama F, Hossain M, Alkafaji YA (2016) The value relevance of components of other comprehensive income when net income is disaggregated. Rev Pac Basin Financ Mark Polic 19:1650027

Zulkafli AH, Amran A, Samad MFA (2010) Board structure and firm value: a study on listed banking firms in the Asian emerging markets. Int J Bus Gov Ethics 5:157-177

Publisher's Note Springer Nature remains neutral with regard to jurisdictional claims in published maps and institutional affiliations. 